\title{
Perspectives
}

Entrepreneurs' Mental Health and Well-Being: A Review and Research Agenda

\begin{tabular}{|r|l|}
\hline Journal: & Academy of Management Perspectives \\
\hline Manuscript ID & AMP-2017-0001.R2 \\
\hline Document Type: & Symposium \\
\hline Keywords: & $\begin{array}{l}\text { Entrepreneurship (General) < Entrepreneurship < Topic Areas, Health \& } \\
\text { safety < Human Resource Management and Industrial Relations < Topic } \\
\text { Areas, Work-related attitudes \& behaviors (e.g. satisfaction, absenteeism, } \\
\text { (turnover) < Human Resource Management and Industrial Relations < } \\
\text { Topic Areas }\end{array}$ \\
\hline
\end{tabular}




\title{
ENTREPRENEURS' MENTAL HEALTH AND WELL-BEING: A REVIEW AND RESEARCH AGENDA
}

\author{
Ute Stephan \\ Aston University \\ u.stephan@,aston.ac.uk
}

\begin{abstract}
Acknowledgements
I am grateful to Ian Macdonald and Sara Klinkebiel for comments and excellent research assistance. The manuscript benefitted from comments received on prior versions from the participants of the Entrepreneurs' Mental Health Workshop at Syracuse University, October 2016 and reviewers for the 2018 Australian Centre for Entrepreneurship Research Exchange (ACERE) Conference. All mistakes are my own.
\end{abstract}




\title{
ENTREPRENEURS' MENTAL HEALTH AND WELL-BEING:
}

\section{A REVIEW AND RESEARCH AGENDA}

\begin{abstract}
Interest in entrepreneurs' mental health and well-being (MWB) is growing in recognition of the role of MWB in entrepreneurs' decision-making, motivation and action. Yet relevant knowledge is dispersed across disciplines, which makes it unclear what we currently understand about entrepreneurs' MWB. In this systematic review I integrate insights from 144 empirical studies. These studies show that research is focused on three research questions: (1) Do different types of entrepreneur differ in their MWB? What are the (2) antecedents and (3) consequences of entrepreneurs' MWB? The review systematizes evidence on known antecedents and consequences of entrepreneurs' MWB but also reveals overlooked and undertheorized sources and outcomes of entrepreneurs' MWB. The review provides a mapping and framework that advance research on entrepreneurs' MWB and help to position entrepreneurs' MWB more centrally in management and entrepreneurship research. It calls for researchers to go beyond applying models developed for employees to understand entrepreneurs' MWB. Instead, the findings point the way to developing a dedicated theory of entrepreneurial work and MWB that is dynamic, socialized, open to considering context, and acknowledges variability and fluidity across entrepreneurs' life domains, as well as the centrality of work for entrepreneurs' identity.
\end{abstract}

Keywords: review, well-being, mental health, entrepreneurship, work design, context, personality 
Entrepreneurs' Mental Health and Well-Being: A Review and Research Agenda

Entrepreneurs create jobs and contribute to economic productivity and growth (see Van Praag \& Versloot, 2008 for a review). They are an essential element of dynamic economies. While the economic benefits of entrepreneurial activity are clear, the outcomes for the individual entrepreneur appear paradoxical. Being an entrepreneur has been characterized as one of the most stressful jobs (Cardon \& Patel, 2015; Patzelt \& Shepherd, 2011), with average earnings that are lower than if entrepreneurs were to work as paid employees (Van Praag \& Versloot, 2008). Despite this, entrepreneurs report being extremely happy in their work and highly satisfied with their life (Benz \& Frey, 2004; Stephan \& Roesler, 2010). Why might this be? What do we know about the sources of entrepreneurs' mental health and well-being? Why, and for what outcomes, does the mental health and well-being of entrepreneurs matter?

Mental health is defined by the World Health Organization (WHO) as not merely the absence of mental health problems but as a "state of well-being in which every individual realizes his or her own potential, can cope with the normal stresses of life, can work productively and fruitfully, and is able to make a contribution to her or his community." (WHO, 2014). Mental health and well-being (MWB) are traditionally researched in psychology, medicine, and public health, but are receiving increasing attention in other disciplines. An example of this broader interest is the effort to develop national well-being accounts (e.g., 'Beyond GDP', European Commission, 2016; Stiglitz, Sen, \& Fitoussi, 2009). To most people, MWB is a valued outcome in its own right - we want to be 'happy' - and we perform better when we are feeling well (Lyubomirsky, King, \& Diener, 2005).

MWB is central to effective human functioning (Ryan \& Deci, 2001; Ryff, 2017) and entrepreneurs are no exception. 'Happy' entrepreneurs are more likely to persist and perform better (e.g., Wincent, Örtqvist, \& Drnovsek, 2008). High MWB is an ongoing benefit that entrepreneurs derive from their work and, at least in part, generate through their work. 
Entrepreneurs may make financially costly decisions, such as delaying business failure, to protect their well-being (Shepherd, Wiklund, \& Haynie, 2009), they value MWB and see it as an indicator of their success (Wach, Stephan, \& Gorgievski, 2016). Thus, research on entrepreneurs' MWB is critical to understanding entrepreneurial action, decision-making, and motivation (e.g., Shepherd \& Patzelt, 2015) and ultimately helps to sustain the economic and societal benefits of entrepreneurship.

For all these reasons, interest in entrepreneurs' MWB is growing. Even though it found its way into the entrepreneurship journals only relatively recently ${ }^{1}$, a substantial body of relevant research on entrepreneurs' MWB exists in other disciplines, such as organizational psychology, economics, and occupational health research. For instance, organizational psychologists investigate predictors of entrepreneurs' MWB and have linked the level of MWB to performance (Gorgievski \& Stephan, 2016). Economists see well-being as a way of understanding the non-monetary returns of entrepreneurship (Van Praag \& Versloot, 2008). Occupational health research seeks to document the health risks associated with occupations including entrepreneurship, often through epidemiological studies.

However, there is little exchange across disciplines, and the research on entrepreneurs' MWB remains fragmented. This means there is no shared base of knowledge and only piecemeal theorizing on entrepreneurs' MWB. We lack an overview of the antecedents and consequences of entrepreneurs' MWB, and the extent to which they are underpinned by robust evidence. Parallel lines of inquiry exist, but without an integrative framework they can give the impression of confusing findings as to the nature of entrepreneurs' MWB. The purpose of this review is to take stock, outline areas of consensus,

\footnotetext{
${ }^{1}$ The review identified four publication on entrepreneurs' MWB in entrepreneurship journals between 1950 and 2010, and 22 since then (up to June 2017).
} 
identify conflicting findings, highlight gaps in our knowledge, and develop a framework for research on entrepreneurs' MWB.

By synthesizing evidence from 144 empirical studies that I identified through a systematic review approach (Tranfield, Denyer, \& Smart, 2003), the review provides a platform and framework for future research by integrating what we know about entrepreneurs' MWB. In doing so, it advances research on entrepreneurs' MWB and helps to position it more centrally in management and entrepreneurship research. Specifically, the review findings identify new overlooked antecedents (entrepreneurs' motivation, their human capital, firm and financial characteristics, the market and social context) and consequences (for others around the entrepreneur and possibly for collectives) of entrepreneurs' MWB. The review also documents evidence on known antecedents (work, personality and social characteristics) and consequences (persistence, performance and work behaviors) of entrepreneurs' MWB.

Building upon these findings, the review points the way to developing a new dedicated theory of entrepreneurial work and MWB. This theory goes beyond the models developed for employees that have to date dominated research on entrepreneurs' MWB while failing to take account of the uniqueness of entrepreneurship. Instead it offers and encourages a much more dynamic, socialized and contextualized view of entrepreneurs' work and their MWB. It acknowledges heterogeneity among entrepreneurs and pays tribute to entrepreneurs' fluid and variable work-life settings, the centrality of work for their identity, the importance of other individuals within and outside of their firm, and the critical impact of market and country contexts on entrepreneurs' work and MWB.

\section{Background to the Review}

First, I will clarify the key concepts of the review: namely, entrepreneurship, mental health and well-being. I will then introduce the main perspectives for this research. 


\section{Entrepreneurship}

Entrepreneurship is often understood as 'new entry', i.e., the creation of a new venture (e.g., Gartner, 1989), or more broadly as an occupational choice of individuals to work for themselves on 'their own account and risk' (Hébert \& Link, 1982). The latter definition includes self-employment and is commonly used in research on well-being and entrepreneurship (Gorgievski \& Stephan, 2016). It also guides this review. The presentation of the findings distinguishes types of entrepreneurs where possible.

\section{Mental Health and Well-being}

The reviewed literature used, with varying meanings, terms such as mental health, psychological or subjective well-being, and distress. The WHO definition illustrates that mental health and well-being (henceforth 'mental well-being' or 'MWB') may be understood as a continuum; and this understanding underpins the review. At one end, we find mental health problems, or ill-being, such as affective, anxiety and personality disorders (e.g., major depression, generalized anxiety disorder $)^{2}$ that impair individuals' daily functioning; as well as less severe feelings of distress (e.g., feeling anxious, tense, sad, or 'down') that reduce individuals' quality of life. At the other end, we find well-being i.e. the experience of "living in a state that is in some sense good" (Warr, 2013, p. 77), characterized by feelings of satisfaction, happiness or "optimal psychological functioning and experience" (Ryan \& Deci, 2001, p.142). Two types of well-being are often differentiated.

Hedonic well-being refers to happiness in terms of attaining pleasure and avoiding pain (Kahneman, Diener, \& Schwarz, 1999; Ryan \& Deci, 2001). It has three components: life satisfaction; the presence of positive affect, and the absence of negative affect (Diener, Suh, Lucas, \& Smith, 1999). While affect is emotion-based, life satisfaction contains a

\footnotetext{
${ }^{2}$ For the full description of all mental disorders see the Diagnostic and Statistical Manual of Mental Disorders (DSM) or the International Statistical Classification of Diseases and Related Health Problems (ICD, chapter 5).
} 
cognitive, evaluative component. ${ }^{3}$ Eudaimonic well-being entails meaning, self-realization, the 'degree to which a person is fully functioning', feels alive, 'thriving' and authentic (Ryan \& Deci, 2001). It is related to resilience and adaptability in adverse situations (Ryff, 2017). Eudaimonic well-being stems, for instance, from succeeding in effortful, self-determined activities (Ryan \& Deci, 2001; Ryff, 2017), a description that seemingly fits entrepreneurship well. It goes beyond experiencing feelings of satisfaction and pleasure derived from achieving valued outcomes or goals, which are characteristic of hedonic well-being.

MWB can be measured at varying levels of abstraction. General MWB describes broad tendencies over time that are not related to a specific life domain, object, or event. Domain-specific indicators such as work-related affect and job satisfaction are often used in research on entrepreneurs. Life satisfaction as a general indicator is positively related to satisfaction with domains such as work, family or leisure time (Bowling, Eschleman, \& Wang, 2010). For entrepreneurs, job satisfaction is more closely related to satisfaction with life, family and self than it is for employees, reflecting the centrality of work in their life (Loewe, Araya-Castillo, Thieme, \& Batista-Foguet, 2015; Thompson, Kopelman, \& Schriesheim, 1992).

The presentation of review findings differentiates indicators of MWB including mental disorders, distress, hedonic and eudaimonic well-being as well as general and domainspecific indicators as much as possible. The online supplement contains further detail.

\section{Dominant Perspectives on Entrepreneurs' MWB in Current Research}

\footnotetext{
${ }^{3}$ The terms emotions and well-being are sometimes used interchangeably in the literature. Thus, a clarification seems in order. The different forms of MWB described above and covered in this review are distinct from but related to emotions. In contrast to $\mathrm{MWB}$, emotions are situation-specific reactions and relatively short lived. A range of emotions with similar valence underlie positive and negative affect respectively (Ashkanasy \& Dorris, 2017). Day-to-day emotional experiences can be seen as micro-foundations of MWB; they underpin and aggregate up to more general, longer-lasting experiences of distress and (hedonic) well-being. Studies exploring emotions as micro-foundations of MWB are included in the review. Yet emotions are an important research area in their own right (Ashkanasy \& Dorris, 2017) including in entrepreneurship (Cardon, Foo, Shepherd, \& Wiklund, 2012). A review of research on emotions and entrepreneurship falls outside the scope of this review.
} 
Research on entrepreneurs' MWB has been primarily conducted from organizational psychology, economics, and occupational health perspectives. Although their emphasis varies, these three perspectives take as their starting point salaried employees, and they then highlight differences in the nature and quality of work of entrepreneurs. Similar arguments are found in entrepreneurship research. They emphasize that entrepreneurs face working conditions that are more extreme than those of salaried employees, including higher levels of uncertainty, responsibility, and complexity; more intense time pressures; and longer working hours. These work characteristics are stressors because individuals typically experience them as overwhelming and appraise them as threating (Lazarus \& Folkman, 1984). Occupational health and psychological research has established the detrimental effects of these stressors for employees’ MWB (Hausser, Mojzisch, Niesel, \& Schulz-Hardt, 2010; Humphrey, Nahrgang, \& Morgeson, 2007; Parker, 2014) and expects similar effects on entrepreneurs' MWB.

Entrepreneurs are also seen to have significantly higher autonomy or job control than employees. They can choose the type and content of their work, have freedom over how to organize and schedule their tasks, and have no superiors to answer to. High autonomy can shape how job stressors are experienced, namely as less threating, stressful or straining (Hausser et al., 2010). For example, high autonomy allows one to alleviate time pressure by rescheduling tasks. Research on employees links job autonomy with eudaimonic well-being because it allows individuals to focus on meaningful activities that develop their skills (Parker, 2014). The economic perspective similarly highlights autonomy as both a key benefit of entrepreneurship that attracts individuals to become entrepreneurs; and a source of wellbeing (cf. 'procedural utility'4, e.g., Benz \& Frey, 2004).

\footnotetext{
${ }^{4}$ Procedural utility suggests that people do not only care about instrumental outcomes, e.g., income, but also value the way they obtain outcomes, e.g. having a say over how to conduct their work (job autonomy).
} 
Occupational health and psychological research also draws attention to social stressors and resources as important working conditions influencing MWB (Karasek \& Theorell, 1990). Social support from supervisors and colleagues are key sources of employees' well-being (Luchman \& González-Morales, 2013), but they are rarely available to entrepreneurs who have no superiors and far fewer, if any, colleagues (co-entrepreneurs). Entrepreneurs' work may therefore be relatively 'lonely', lacking important sources of workrelated social support, which is likely detrimental to their MWB.

Finally, entrepreneurs differ from salaried employees in their personality traits, especially in traits such as self-efficacy, need for achievement (Frese \& Gielnik, 2014 for an overview), and psychological capital (Baron, Franklin, \& Hmieleski, 2016). Thus, rather than being a direct result of their work, entrepreneurs' MWB may be a reflection of self-selection processes (Baron et al., 2016), such as those described in the Attraction-Selection-Attrition framework (Schneider, 1987). Individuals that are more 'stress-resistant' may elect to start businesses and are likely to be reinforced in their choice by stakeholders (e.g. investors). In turn, they are likely to persist as entrepreneurs, because they are able to cope with the high demands of their work.

Researchers often focus on aspects of the above arguments to suggest MWB benefits or costs for entrepreneurs. This fragmentation means that it is difficult to know what we currently understand about entrepreneurs' MWB, what factors give rise to it and its consequences. Hence this review takes stock of the evidence across different perspectives.

\section{Review Method and Overview of Reviewed Studies}

I followed the systematic review procedure (Tranfield et al., 2003). First, I used Web of Science to retrieve sources. Web of Science covers research across disciplines (management, medicine, epidemiology, occupational health, economics, and psychology), in which relevant evidence is likely to be published. It also includes conference proceedings to access research 
before it is formally published. I used a range of keywords, specifying entrepreneurs and selfemployed combined with search terms for MWB and its spectrum of facets, ranging from disorders, distress to well-being. The full set of 68 search terms is available upon request. I searched in abstract, titles and keywords, and included sources published between 1950 and June 2017. The searches retrieved 2,121 results (in June 2017).

Second, I coded these results for inclusion in the review, based on reading the title and abstract. Sources were considered relevant if they explored the MWB of entrepreneurs by, for example, identifying predictors of entrepreneurs' MWB or exploring its consequences. This narrowed the search results to 301 sources. When no definite exclusion decision could be made, I erred on the side of including a source for further evaluation.

Third, I read the 301 papers in detail and coded their research design, the nature of the sample, the country of data collection, the theoretical approach, disciplinary background, and key findings, as well as the concept and measure of MWB.

Sources were excluded in step two and three if they mentioned well-being but referred exclusively to economic well-being, or when they mentioned that entrepreneurs were not part of the sample. I also excluded studies that did not present separate results for entrepreneurs, such as when managers and entrepreneurs were treated as one group. To keep the review manageable, I focused on explanatory studies that offered insights into antecedents or consequences of entrepreneurs' MWB, and on empirical studies. I included studies that compared entrepreneurs and employees only if they offered an empirical explanation for MWB differences, for instance, by measuring autonomy or personality traits. I excluded studies that merely described the MWB levels of entrepreneurs and employees. I also excluded studies of social enterprises offering mental health provision.

Fourth, I conducted reference searches. I retrieved references that were mentioned in the sources but not yet included in the review. I also scanned the advanced online 
publications and papers published in the leading entrepreneurship journals (Journal of Business Venturing, Entrepreneurship Theory and Practice) in the last five years. Overall, I identified 144 relevant sources. Of these, three were conference proceedings, one was a book chapter, and the remainder were journal publications.

Before delving into the findings, I give an overview to illustrate how past research has studied entrepreneurs' MWB. The dominant research approach in the 144 studies was survey-based quantitative $(90 \%, 8 \%$ qualitative, $3 \%$ mixed-method). The studies focussed on individuals (92\%) as the level of analysis, and employed cross-sectional (67\%) or longitudinal/lagged research designs (25\%). Three percent (five studies) were interventions or randomized control trials. Another three studies were diary/experience sampling studies, two were case studies, and one an ethnography. In terms of levels of analyses other than the individual, $2 \%$ (three studies) focussed on the family, $2 \%$ on within-individual variation, and $2 \%$ were multi-level studies considering individuals in their country contexts. One percent (two studies) were conducted on the country-level of analysis.

With regards to measures of $M W B, 39 \%$ of the 144 studies included measures of mental 'ill-being' (e.g., distress, mental health complaints, burnout, mental disorders), 39\% measured well-being (e.g., life satisfaction, happiness, job satisfaction), a further $15 \%$ measured both ill- and well-being in the same study, and 7\% captured 'other' measures (e.g., Quality of Life measures that contain aspects of both psychological and physical MWB). Just over half (53\%) of the studies included measures of general MWB (e.g., life satisfaction or general distress), 27\% included work-related well-being measures (e.g., job satisfaction or work-related distress), 19\% included measures of both and 1\% 'other' measures.

I classified the primary disciplinary approach based on the study's theoretical background in combination with the journal where it was published. The disciplinary approaches were psychology (23\%), occupational health and medicine $(22 \%)$, 
entrepreneurship (18\%), economics (16\%), management $(12.5 \%)$, and the remainder were other social sciences.

\section{Synthesis and Analysis of Review Findings}

As noted above, I coded all studies in detail for a range of characteristics. This allowed me, in the first instance, to cluster studies by their primary research question. Sixteen studies explored MWB across different types of entrepreneur, 105 studies investigated antecedents of MWB, and 28 studies explored the consequences of MWB. Five of the 144 studies provided information on two research questions simultaneously. A summary of the coding tables and each study is included in the Online Supplement. Tables A1, A2 and A3 list all the studies on MWB and types of entrepreneurs, antecedents of entrepreneurs' MWB, and on MBW consequences respectively.

To synthesize findings in each of the three areas, I engaged in qualitative coding and abduction. For instance, I identified common clusters of antecedents of MWB guided by my knowledge about work, social and personality characteristics as possible antecedents of entrepreneurs' MWB as well as guided by the 'data', i.e. the findings that emerged from the individual studies in the review. An example of 'data-driven'/ inductive coding is the fact that new categories of stressors and resources started to emerge from the studies. These included firm characteristics such as its financial situation and physical environment, as well as context characteristics (e.g., the level of competition, the business climate, and cultural aspects). The coding also revealed greater differentiation of personal characteristics such as human capital and values, in addition to traits. I similarly employed qualitative coding and abduction to cluster studies on the different consequences of entrepreneurs' MWB, and on the types of entrepreneurs and their MWB.

\section{Review Findings}


The findings are presented along the three primary research questions that emerged from the coding of studies: (1) Does MWB differ by type of entrepreneur? What are the (2) antecedents and (3) consequences of entrepreneurs' MWB? Figure 1 provides a visual mapping of the review findings, including the general concepts studied as antecedents and consequences of MWB in the 144 studies. Tables 1 and 2 map the specific antecedents and consequences studied, their relationship with MWB in the reviewed studies, the frequency and number of high-quality studies, as well as notes on unexpected findings.

--- insert Figure 1 about here ---

\section{Prelude: MWB and Types of Entrepreneur}

Sixteen studies investigated whether different types of entrepreneur are 'better off' in terms of MWB. These studies are largely descriptive and their findings consistent.

Entrepreneurs who may be broadly characterized as opportunity entrepreneurs experienced higher MWB than necessity entrepreneurs (Online Supplement Table A1 for the list of individual studies). With one exception ${ }^{5}$, all studies found that opportunity entrepreneurs were 'happier' and less distressed than necessity entrepreneurs. One study across 74 countries suggests a similarly positive relationship between national rates of opportunity entrepreneurship and life satisfaction (Naudé, Amorós, \& Christi, 2014).

The MWB benefits of being an opportunity versus necessity entrepreneur were evident in both cross-sectional and longitudinal studies (all studies were based on random, representative samples). They held for differing ways of identifying opportunity and necessity entrepreneurs; for instance, based on whether they transitioned into selfemployment from employment or unemployment, their preferences and desire for self-

\footnotetext{
${ }^{5}$ The one exception was a study that found descriptively the expected differences between entrepreneurs with and without employees in subjective quality of life, as an overall assessment that combines both mental and physical health - but these became non-significant after adjusting for controls (Saarni, Saarni, \& Saarni, 2008). This was the only study that used a measure of MWB that may be confounded by physical health.
} 
employment, the number of employees (or none), whether they were skilled or unskilled, ran an incorporated business or sole proprietorship, were independent or dependent contractors, or were formally or informally self-employed. The differences were also robustly found for different types of MWB indicators. The most frequently studied were: in five studies, life and job satisfaction; in four studies, distress (anxiety, depressive symptoms, burnout); two studies concerned suicide mortality; and two studies researched subjective well-being (combining satisfaction and affect). Moreover, opportunity entrepreneurs had higher family and health satisfaction than necessity entrepreneurs, but both types of entrepreneurs were equally dissatisfied with the lack of leisure time (Binder \& Coad, 2016; Johansson Sevä, Larsson \& Strandh, 2016).

To explain these differences, the reviewed studies referred either to the higher autonomy and deliberate choice that opportunity versus necessity entrepreneurship involved, or to differences in human capital (education), personality traits, and preferences (e.g., higher desire for independence or power among opportunity entrepreneurs, Binder \& Coad, 2016; Petrescu, 2016; Van den Heuvel, \& Wooden, 1997). While empirical tests were rare, opportunity entrepreneurs indeed reported more autonomy and in one study they experienced growing life, job and health satisfaction over the first three years after starting their firm (Binder \& Coad, 2016). This pattern is consistent with the view that the effects of autonomy take time to unfold (Ford et al., 2014). It is also consistent with another study that found that entrepreneurs that are established have higher MWB than those starting out (Zbierowski, 2014). In two further studies the MWB differences between opportunity and necessity entrepreneurs were partly explained by education (Sikora \& Saha, 2009), and by entrepreneurial traits, desire for independence and intrinsic work motivation (Johansson Sevä, Larsson, et al., 2016). These findings point to possible antecedents of entrepreneurs' MWB. 
I present antecedents according to whether they have positive effects (resources) or negative effects (in the form of stressors or vulnerabilities) on entrepreneurs' MWB. The antecedents studied clustered into six broad categories: work characteristics (49 studies); personality traits; values and other personal resources (54 studies); firm and financial characteristics (37 studies); social support and stressors (25 studies); market- and country context (26 studies); and physical context (four studies). Table 1 gives an overview of the findings by listing: the characteristics identified in each of the six categories; how many times they were studied; and the relationship with entrepreneurs' MWB. Table 1 also reports the number of studies with stronger research designs (longitudinal, lagged, and experience sampling design, as well as experiments). In the following synthesis of findings I focus on the most frequently studied characteristics as well as the unexpected findings. I privilege studies with stronger research designs to provide examples. Table A2 in the Online Supplement lists and summarizes each study in this stream.

--- insert Table 1 about here ---

Work characteristics. Work characteristics broadly describe the nature and organization of entrepreneurs' work tasks and activities (cf. Parker, 2014). Of the 49 studies that included measures of work characteristics, 13 had longitudinal or lagged study designs. Intuitively two features of entrepreneurs' work stand out, entrepreneurs have high autonomy they can make decisions about what, when and with whom to work (Parker, 2014) - and they have 'stressful' jobs - high work demands that require intense effort and concentration (Karasek, 1979). Autonomy, also called job control, and work demands are the two dimensions of the Job Demand Control Model (Karasek, 1979), a well-supported model of work stress (e.g. Hausser et al., 2010). These two aspects were also the two most frequently studied work characteristics in the review, and the pattern of findings (Table 1) confirms expectations that autonomy is positively related and demands are negatively related to MWB. 
Two studies found no effect of autonomy and demands on MWB. One was based on a small sample of $N=53$ (Rau et al., 2008). The other study was a longitudinal study but alongside the measure of work autonomy it included farm-specific work characteristics that were more powerful predictors of MWB (Wallis \& Dollard, 2008).

Studies investigated two further measures of work stressors that are closely related to work demands. For role stress (Kahn, Wolfe, Quinn, Snoek, \& Rosenthal, 1964), six studies consistently showed negative effects on entrepreneurs MWB. For working hours, one study found that a subset of starting entrepreneurs were more satisfied with their work if they experienced high demands and also worked long hours (Bradley \& Roberts, 2004). It was interpreted as a signal that the business is doing well. A large cross-country study also found a positive association of longer working hours with higher MWB (Millán, Hessels, Thurik, \& Aguado, 2013). These mixed findings suggest that entrepreneurs can appraise long working hours as a challenge stressor, i.e. as a stressor that is perceived to entail opportunities for future achievement (Podsakoff, LePine, \& LePine, 2007, see also discussion section).

Among the studies investigating working hours, four referred to recovery processes, understood as the processes of recuperating from work demands through detachment from work and engagement in leisure activities (Sonnentag \& Fritz, 2015). Two found that taking time off work enhanced entrepreneurs' MWB (cross-sectionally for the length of vacation time, Rau et al., 2008, and when comparing entrepreneurs' MWB before and after a recovery retreat, Vesala \& Tuomivaara, 2015). Entrepreneurs themselves also considered vacation time as a resource for their well-being in a qualitative study (Lechat \& Torrès, 2017). In another cross-sectional study, working long hours were no longer related to entrepreneurs' MWB when recovery processes were also taken into account. Entrepreneurs that were able to mentally detach from work in their leisure time were unaffected by working long hours (Taris, Geurts, Schaufeli, Blonk, \& Lagerveld, 2008). 
With regard to other work resources, time flexibility had the expected positive effects on MWB even when considered alongside autonomy with which it overlaps (see Table 1 for details). The ability to make use of one's skills at work (skill utilization) also tended to have positive effects (see Table 1 for details). The remainder of the work resources considered were features that describe motivating work settings in the Job Characteristics Model (JCM, Hackman \& Oldham, 1975; autonomy is also contained in this model). These features are the significance or meaningfulness of work, how interesting and varied the work is, how coherent it is (task identity), and whether work offers an opportunity for feedback on one's actions and thus opportunities to learn. Two studies were explicitly based on the JCM and supported these relationships, except for task identity (Hytti, Kautonen, \& Akola, 2013; Schjoedt, 2009). Other studies investigated individual JCM features and also found the expected positive effects (Table 1). Yet, two qualitative studies suggest that work can become too significant to entrepreneurs, and all-consuming, which implies an inverse-U shaped relationship of meaningfulness with MWB (Fisher, Maritz, \& Lobo, 2013; Spivack, McKelvie, \& Haynie, 2014) - an intriguing avenue for future research (see discussion). Studies that included samples of salaried employees consistently found that entrepreneurs reported higher autonomy. This was true for both opportunity and necessity entrepreneurs, although the former reported the highest level of autonomy (Johansson Sevä, Larsson et al., 2016). Autonomy, sometimes alongside other work characteristics, explained the majority (Benz \& Frey, 2008) or all of the difference in work satisfaction between entrepreneurs and employees (Hytti et al., 2013; Prottas \& Thompson, 2006).

Studies of work characteristics imply a malleable view of entrepreneurs' MWB, which contrasts with the self-selection view of the personality perspective (Baron et al., 2016). Research combining personality and work characteristics would allow testing of competing explanations of selection versus work characteristics, but such research was 
sparse. Studies in the review that explored both work and personality suggest that the two explanations are compatible, and interact to shape entrepreneurs' MWB. Lange (2012) found that work autonomy accounted for the MWB differences between entrepreneurs and employees when controlling for differences in personality traits and values. Although crosssectional, this study suggests that work characteristics help explain MWB benefits in addition to self-selection effects. In a diary study over 25 weeks, Totterdell, Wood and Wall (2006) found that weekly variations in autonomy and demand predicted changes in entrepreneurs' MWB (distress). Trait optimism moderated these effects. It further boosted the beneficial effects of high autonomy/high demand work (the so-called active job), while pessimism worsened the effects of high-strain jobs (low autonomy/high demand).

Personality traits, values and other personal resources and vulnerabilities. Of the 53 studies that included measures of personal resources and vulnerabilities, 14 employed stronger research designs (longitudinal, lagged, experimental or experience sampling). Most frequently studied were personality traits ( 27 studies), followed by human capital (education and specific skills, 13 studies), entrepreneurs' values and motivations (12 studies), and 'other' characteristics (eight studies). See Table 1 for an overview.

Personality traits. Most studies investigated personality traits as resources that would enhance entrepreneurs' MWB. Table 1 shows the range of different traits studied, including psychological capital traits, traits that are associated with entrepreneurship such as risktaking and internal locus of control, and the Big Five personality traits (e.g., Baron et al., 2016; Przepiorka, 2017). They showed overwhelmingly the expected beneficial effects on entrepreneurs' MWB (Table 1) including in the rare longitudinal and lagged studies (Laguna, Razmus, \& Żalisńki, 2017; Roche, Haar, \& Luthans, 2014).

There are a small number of exceptions to this pattern. These point to inverse- $U$ shaped relationships or 'optimum levels' beyond which even traits that are widely considered 
to be resources for personal well-being (self-efficacy and optimism) can have negative effects. In one study, self-efficacy moderated the effect of entrepreneurs' improvisational behavior on their work satisfaction (Hmieleski \& Corbett, 2008). Entrepreneurs that were both highly self-efficacious and engaged in improvisation were least satisfied, even though further results suggested that they were also the ones leading the most dynamically growing companies. These entrepreneurs may have been overexerting themselves. Similarly, one longitudinal study found that optimism can lead to lower MWB in the longer term when overly positive expectations do not materialise (Dawson, 2017). High levels of optimism before starting a business led to lower work satisfaction and lower satisfaction with pay once the individual became an entrepreneur. Yet in the shorter term, optimism benefitted entrepreneurs' MWB as reported in a 25 -week diary study (Totterdell et al., 2006) and in a cross-sectional study on samples from 19 European countries (Lange, 2012).

Coping styles were investigated as habitual approaches to dealing with challenging situations. All studies found the expected positive effects of problem-focussed and related proactive coping styles on MWB (e.g., Drnovšek, Örtqvist, \& Wincent, 2010; Müller \& Gappisch, 2005). Two studies additionally pointed to the functionality of emotion-focussed coping styles to enhance MWB (Patzelt \& Shepherd, 2011; Uy, Foo, \& Song, 2013).

In terms of vulnerabilities, neuroticism and related constructs of trait negative affect expectedly reduced entrepreneurs' MWB in all five studies that investigated this relationship (e.g., Bradley \& Roberts, 2004; Morrison, 1997). Entrepreneurs that were high in fear of failure also had lower MWB in one study (Bahmannia, Tharan, \& Wang, 2013).

Human capital. Human capital describes the skills acquired through experience and education (Becker, 1964). Due to their broader skills set, individuals with high human capital should be better able to cope with the demands of entrepreneurial work. Indeed, entrepreneurs reported that they experience their low or deficient business and 
entrepreneurial skills as stressful (Ahmad \& Arabia, 2010; Vaag, Giæver, \& Bjerkeset, 2014). One study investigated the effect of business skills on MWB in a randomized control trial with microfinance entrepreneurs. Business skills training, whether on its own or in combination with the provision of longer-term access to finance, had positive effects on the MWB of male entrepreneurs (Berge, Bjorvatn, \& Tungodden, 2015) ${ }^{6}$.

The effects of stress and self-management skills on entrepreneurs' MWB were positive in two studies. This included a randomized control trial on entrepreneurs who were on sick leave due to mental health issues, training them in self- and stress-management (Blonk, Brenninkmeijer, Lagerveld, \& Houtman, 2006). By comparison the effects of past experience were not clear cut (see Table 1), likely because the measures of experience were coarse and typically considered the length rather than the quality of the experience. A case in point is a cross-sectional study in which the MWB of entrepreneurs was negatively related to the number of times they had failed with past businesses (Zhang, Chen, Li \& Zhou, 2016).

The findings for education were ambivalent (see Table 1) even in two longitudinal studies. It is likely that two countervailing processes are at work; the broader skills set associated with education can indeed yield MWB benefits (Millan et al., 2013), but at the same time, better education entails higher opportunity costs for the entrepreneur. Highly educated entrepreneurs are able to achieve significant income in paid employment. Such comparison processes may make highly educated entrepreneurs relatively less satisfied with their work. Dawson's (2017) longitudinal study is consistent with this explanation. The highly educated entrepreneurs reported lower satisfaction with both their work and their pay than did less well-educated entrepreneurs. Kwon and Sohn (2017)'s study suggests that the negative MWB impact of opportunity cost considerations is particularly salient in emerging

\footnotetext{
${ }^{6}$ For female entrepreneurs the effects were non-significant. This is probably due to a combination of factors, including the fact that their husbands exerted control over their wives' businesses and earnings. Women's lower willingness to compete may also play a role, as may the extent to which their expectations of the intervention were disappointed (Berge et al., 2015).
} 
economies where employed work is held in higher social esteem than entrepreneurship. In their study in Indonesia, the most highly skilled self-employed were least satisfied with their work and, conversely, those with the lowest qualifications were most satisfied.

Personal motivations and values. Motivations and values refer to specific and general goals that energize actions, thus they describe 'why' people engage in actions while personality traits describe 'how' people typically act (Roccas, Sagiv, Schwartz, \& Knafo, 2002). All 12 studies that related entrepreneurs' motivations and values to their MWB are cross-sectional, thus the findings are best described as correlates of entrepreneurs' MWB. Table 1 shows a consistent pattern that is in line with extant motivational theories such as self-determination theory (Ryan \& Deci, 2000). Entrepreneurs' that were driven by intrinsic motivations (both general and specific intrinsic values) exhibited higher MWB than those motivated by extrinsic factors such as financial success. At the same time achieving the goals the entrepreneurs' had set themselves was also positively associated with higher MWB.

Other personal characteristics. A range of other personal characteristics were investigated and to detail the findings for all of them (often included as control variables in regressions) would go beyond the scope of the review. Two findings are noteworthy, better physical health and health maintenance behaviors (e.g., exercise) were positively related to entrepreneurs MWB. Being an immigrant entrepreneur also had MWB benefits in two studies including one longitudinal study, which also suggested that these benefits may become smaller for subsequent generations (Clark, Colombier, \& Masclet, 2008).

Firm and financial characteristics. Firm and financial characteristics were considered as both objective and subjective resources and stressors (e.g., perceptions of firm success, income uncertainty, and financial problems). Subjective perceptions of success can be more decisive for entrepreneurs' action than objective factors (Gimeno, Folta, Cooper, \& 
Woo, 1997); a finding that also plays out in the reviewed studies. Of the 37 studies investigating firm and financial characteristics, 15 had stronger research designs (Table 1).

Firm and financial resources. Overall the effects of personal financial rewards and perceived firm success on entrepreneurs' MWB were positive, while the MWB-effects of objective indicators of firm performance, size and financial resources were more nuanced.

Income and related financial rewards derived from the firm related positively to entrepreneur' MWB in all studies that investigated such rewards, including in longitudinal studies (Dawson, 2017; Millan et al., 2013). Moreover, entrepreneurs' subjectively perceived firm success was positively related to their MWB in five cross-sectional studies. Similarly, in qualitative research, entrepreneurs named firm performance, growth, and success as important sources of their MWB (Lechat \& Torrès, 2017).

Only two studies investigated objective firm performance, and they failed to establish the expected positive effects. In a cross-sectional study, those entrepreneurs whose firms were performing well experienced lower well-being and leisure satisfaction, although they were highly satisfied with their income (Carree \& Verheul, 2012). This points to important trade-offs across well-being domains. In a longitudinal study, business owners' mental recovery after a disaster was unrelated to the economic performance of their firms (de Mel, McKenzie, \& Woodruff, 2008). At the same time, entrepreneurs leading larger firms (with a higher number of employees) reported higher well-being in three studies. It is worth noting that one longitudinal study paints a more nuanced picture by also considering work characteristics: entrepreneurs with employees experienced higher work demands than those without employees, which in turn increased their level of distress (Hessels, Rietveld, \& Van der Zwan, 2017).

In line with the rationale that the effect of firm resources is mediated by subjective experiences, two randomized control trials did not find positive effects of the availability of 
financial resources on micro-credit entrepreneurs' MWB. Indeed, entrepreneurs' well-being declined slightly, and distress increased in the treatment group receiving loans, because the expansion of business activities increased entrepreneurs' workload (Karlan \& Zinman, 2011). Similarly, the effect of obtaining long-term finance on the happiness of entrepreneurs was contingent upon also receiving business skills training, in part because of the boost to the entrepreneurs' confidence (Berge et al., 2015).

Firm and financial stressors. All studies that investigated firm financial problems found that these lowered entrepreneurs' MWB (Table 1). This was the case for all crosssectional (Annink, Gorgievski, \& Den Dulk, 2016; Kallioniemi, Simola, Kaseva, \& Kymäläinen, 2016; Kallioniemi, Simola, Kymäläinen, Vesala, \& Louhelainen, 2009; Torp, Syse, Paraponaris, \& Gudbergsson, 2017) and two longitudinal studies (over three years, Gorgievski, Bakker, Schaufeli, Van der Veen, \& Giesen, 2010; and one year, Wallis \& Dollard, 2008). The exception was a study of a smaller sample of 91 farmers over 10 years (Gorgievski-Duijvesteijin, Giesen, \& Bakker, 2000). Entrepreneurs also perceived financial problems as a key stressor in a qualitative study (Lechat \& Torrès, 2016). Equally three related studies found consistently that entrepreneurs with low income had lower MWB (Anderson \& Hughes, 2010; D’Angelo et al., 2016; Kwon \& Sohn, 2017).

The effects of financial problems and low pay seem to go beyond their material impacts. Entrepreneurs appear to perceive financial problems and poor venture performance as a threat to their self-image and even their identity. Studies investigating job loss and job insecurity/uncertainty are consistent with such a view. They found the expected negative effects on entrepreneurs' MWB; but also that entrepreneurs suffered significantly more distress from job loss, the threat of job loss, and periods of unemployment, than did comparable groups of employees (e.g., in two longitudinally studies Backhans \& Hemmingsson, 2012; Hetschko, 2016). Identity shifts and intense feeling of loss occurred 
even for entrepreneurs who voluntarily retired from their firms (Byrnes \& Taylor, 2015).

Conversely, a longitudinal study found that entrepreneurs who delayed retirement had a lower risk of developing dementia (Dufouil et al., 2014).

Social resources and stressors. Of the 25 studies that investigated social support six had stronger research designs (Table 1). Social relationships are an important source of MWB, and the review shows that this is no different for entrepreneurs irrespective that they have far fewer sources of work-related social support compared to employees (Rahim, 1996; Tetrick, Slack, Da Silva, \& Sinclair, 2000). In a longitudinal study, Fernet, Torrès, Austin and St-Pierre (2016) found that entrepreneurs who were lonely and socially isolated were more likely to develop burnout. When available, social support from others at work and from their family was consistently positively related to entrepreneurs' MWB in cross-sectional and longitudinal studies (Nguyen \& Sawang, 2016; Totterdell et al., 2006). In two cross-sectional studies, social support moderated (mitigated) the effect of other stressors and negative emotional experiences on MWB (Bahmannia et al., 2013; Tetrick et al., 2000).

How entrepreneurs balance their family roles with their work was covered in 11 studies. More studies investigated work-family conflict compared to work-family enrichment (Table 1). Conflicts between the two domains impacted entrepreneurs' MWB negatively in all nine studies in the review, including in a longitudinal study (Nguyen \& Sawang, 2016). A randomized control trial found a negative effect of work-family conflict only for female entrepreneurs (Berge et al., 2015). Three further studies were based solely on samples of female entrepreneurs (Anderson \& Hughes, 2010; McLellan \& Uys, 2009; Ugwu, Orjiakor, Enwereuzor, Onyedibe, \& Ugwu, 2016). A further cross-sectional study separately identified family conflicts as an additional stressor for entrepreneurs (Kallioniemi et al., 2009). More specifically, a study of female entrepreneurs in Tanzania identified their partners' control over their finances and business as a limiting factor for their MWB (Dutt, Grabe, \& Castro, 
2016). Interestingly, this was much less the case for collective entrepreneurship in the form of a co-operative, which provided these women with important peer social support from fellow entrepreneurs. Finally, work-family enrichment was part of three studies that also investigated work-family conflict (McLellan \& Uys, 2009; Nguyen, \& Sawang, 2016; Ugwu et al, 2016). It had consistent positive effects on entrepreneurs' MWB.

The qualitative studies in the review also pointed to new and overlooked social resources and stressors. This includes positive feedback from customers as a resource boosting entrepreneurs' MWB (Anderson \& Hughes, 2010; Lechat \& Torrès, 2017), and conflicts with customers and employees as a significant and frequent social stressor straining entrepreneurs' MWB (Lechat \& Torrès, 2016; Schonfeld \& Mazzola, 2015). One crosssectional study uniquely identified entrepreneurs' felt responsibility for people at work as a strain on their MWB (Begley, 1994).

Context. Twenty-five studies (six with stronger research designs) investigated different layers of context. These included the local business climate, the level of societal esteem of entrepreneurs, and the impact of shocks (see Table 1).

The business climate (or level of demand in the market) was the subject of five studies. A further four studies investigated the related effects of economic recession, and two studied the effect of competition in the market. Collectively these 11 studies provide evidence that entrepreneurs' MWB is shaped by the wider market and economic environment. More specifically, objective measures of economic growth (Johansson Sevä, Vinberg, Nordenmark, \& Strandh, 2016) and business climate (Jiang, Lu, \& Lu, 2017) affected entrepreneurs' MWB positively. Entrepreneurs themselves highlighted the stressful effects of low customer demand in three qualitative studies (Lechat \& Torrès, 2016, 2017; Schonfeld \& Mazzola, 2015). The effects of the recession triggered by the 2008 financial crisis were the subject of a further three studies. One study across 20 European countries did not find a link with 
entrepreneurs' risk of developing depression (Buffel, De Velde, \& Bracke, 2015). Yet, two studies from Spain (a country that was strongly affected by the crisis) found expected changes in entrepreneurs' MWB due to the crisis (Cueto \& Pruneda [2017], based on annual labour force surveys; Real et al. [2016], based on records of diagnosed mental disorders). Equally, a study in China found that a local recession dampened entrepreneurs' MWB (Jiang et al., 2017). Finally, strong market competition strained entrepreneurs' MWB in two longitudinal studies, both directly (Wallis \& Dollard, 2008), and indirectly through increasing role stress (Wincent \& Örtqvist, 2009).

Turning to cultural factors, three cross-sectional studies suggest that the lack of societal esteem for entrepreneurs diminishes their MWB (Kallioniemi et al., 2016; Kwon \& Sohn, 2017). Yet a supportive societal context can also make failing more difficult. Entrepreneurs whose businesses had failed in the past had lower MWB, especially when they perceived their environment to be supportive of entrepreneurship (Zhang et al., 2016).

Five studies investigated context from the perspective of reactions to 'shocks' such as industrial and natural disasters (e.g., chemical explosion, tsunami), and personal trauma (cancer survivors). They again point to the close link of entrepreneurs' work to their identity. In four studies (two cross-sectional, two longitudinal), entrepreneurs were among the groups whose MWB suffered the most due to the shock (Cohidon et al., 2009; De Mel et al., 2008; Torp, Nielsen, Gudbergsson, \& Dahl, 2012; Torp et al., 2017). Another study found that starting a business in the immediate aftermath of a natural disaster can help especially highly educated individuals to cope with the disaster (Williams \& Shepherd, 2016).

Physical working environment. The physical work environment was investigated in four cross-sectional studies (Anderson \& Hughes, 2010; Gunnarsson, Vingard, \& Josephson, 2007; Kallioniemi et al., 2016; Sörensson \& Dalborg, 2017). Poor physical working environments, including a heavy physical work load and the use of toxic materials, strained 
entrepreneurs' MWB. At the same time, for farm and nature entrepreneurs, the physical work environment ('nature') was positively related to their MWB.

\section{Consequences of Entrepreneurs' MWB}

The reviewed research studied the impact of entrepreneurs' MWB on performancerelated outcomes, at the level of the individual entrepreneur by investigating persistence (seven studies), opportunity recognition (five studies), and work behaviors (five studies); and for the performance of entrepreneurs' firms (eight studies). Further studies linked entrepreneurs' MWB to other individual-level outcomes for the entrepreneur (their physical health and stress, one study each) and explored the consequences of entrepreneurs' $M W B$ for others, including the entrepreneurs' families (children and life partner, three studies) and societal conflict (one study). Three studies included measures of two different consequences. Of the 28 studies reviewed in this section, ten employed longitudinal, lagged or experience sampling designs, one was an ethnographic study, and the remaining 17 were cross-sectional studies. Table 2 in the Online Supplement provides details of all studies. Figure 2 is based on the reviewed studies and gives an overview of the type of consequences studied, their possible relationships, and the frequency with they were studied. It also contains additional outcomes that future research could explore, which will be detailed in the discussion section.

---- Figure 2 and Table 2 about here ---

Why would MWB be related to performance outcomes? MWB can act as a selfregulatory mechanism as described in Conservation of Resources Theory (Hobfoll, 2001). Entrepreneurs with high MWB can draw on more cognitive and affective resources to work on the business (Hobfoll, 2001). In particular, the positive affect associated with high MWB broadens thought and action repertoires (e.g., facilitating creativity and opportunity recognition) and in turn helps the building of future resources (as described in the Broadenand-Build theory, Fredrickson, 2001). The studies in the review relating MWB to opportunity 
recognition and work-related behaviors help to unpack such micro-level mechanisms that underpin the MWB-firm performance link. Low MWB triggers efforts to conserve resources, which can mean that entrepreneurs withdraw from this highly demanding activity altogether. Moreover, entrepreneurs see their MWB as an indicator of their success as entrepreneurs (Wach et al., 2016) and, thus, low MWB indicates that they are not achieving their goals, again encouraging withdrawal. I first discuss the evidence that relates MWB to an individuals' persistence in entrepreneurship and their firm's performance, before delving into studies on possible individual-level intervening processes (opportunities and work behaviors), and those considering consequences of entrepreneurs' MWB for others.

Persistence is the lack of withdrawal from entrepreneurial activity. Entrepreneurs with higher MWB were more likely to persist in entrepreneurship in six of the seven studies that investigated it, including in three longitudinal studies (Gorgievski et al., 2010; Patel \& Thatcher, 2014; Wincent et al., 2008). One cross-sectional study found this to be the case only for entrepreneurs who had already fewer resources (low social capital, Pollack, Vanepps \& Hayes, 2012). Other cross-sectional studies found that entrepreneurs with higher MWB were more likely to persist and re-start their business after an external disaster had destroyed it (Kadowaki et al., 2016), while 'happier' older entrepreneurs were more likely to intend to delay their retirement (Kautonen, Hytti, Boegenhold, \& Heinonen, 2012). The one exception was a descriptive cross-sectional study of Bed \& Breakfast owners, in which job satisfaction was unexpectedly positively and work-family balance expectedly negatively associated with exit planning (Crawford \& Naar, 2016). It may be that owners who were satisfied with their work, sought to buy a larger business with employees to increase their work-life balance.

In seven out of the eight studies that investigated $M W B$ and firm performance, 'happier' entrepreneurs led higher performing firms, whether performance was measured as business growth, innovative behavior, perceived success, fewer perceived financial problems 
or customer service quality perceptions. This was true for different MWB indicators of distress, negative affect and eudaimonic well-being (cross-sectionally, Gorgievski, Moriano, \& Bakker, 2014; and longitudinally Gorgievski-Duijvesteijin et al., 2000; Gorgievski et al., 2010) as well as related indicators of coping styles (longitudinally, Ayala \& Manzano, 2014; and cross-sectionally, Örtqvist, Drnovsek, \& Wincent, 2007). Similarly, a study on manic depression (bi-polar disorder) found that entrepreneurs with manic vulnerabilities were more likely to report losses (Johnson, Freeman, \& Staudenmaier, 2015); and a study of hairstylist business owners found that their customers reported higher service satisfaction the more satisfied and committed the owners were (Payne \& Webber, 2006). The exception to this pattern was one longitudinal study in which higher distress predicted higher personal income at the cost of worse physical health (Cardon \& Patel, 2015). Trait positive affect strengthened the stress-income relationship and directly enhanced income. This study is consistent with the view that distress, especially in combination with trait psychological resources, can lead to the mobilization of extra effort and benefit performance. Yet over the longer term the persistent strain on the body damages the physical health (McEwen, 1998).

In addition to entrepreneurs' MWB influencing their physical health (Cardon \& Patel, 2015), one other study investigated outcomes for the entrepreneur. In a longitudinal study, Örtqvist and Wincent (2010) found that exhausted and dissatisfied entrepreneurs were more likely to subsequently perceive their work as more demanding and stressful.

All five studies examining the effects of MWB on opportunity recognition were cross-sectional studies. Lower MWB was related to reduced opportunity recognition, especially for older entrepreneurs (Gielnik, Zacher, \& Frese, 2012) - a finding consistent with a resource-diminishing effect of low MWB, to which more vulnerable entrepreneurs are especially susceptible. Conversely, Rietveld, Bailey, Hessels, \& Van der Zwan (2016) found that healthier business owners saw more opportunities for firm growth. Foo (2011, study 2) 
found that entrepreneurs with high anger as well as those with high happiness identified more uncertain high-value opportunities. Even though anger and happiness differ in valence, they both trigger similar confidence mind-sets, which allow for the exploration of more uncertain opportunities. Foo's (2011) study thus points to a potential upside of low MWB, as do two studies that explored ADHD and ADHD-like symptoms. In particular, the impulsivity component of ADHD was positively related to entrepreneurs' opportunity development (Wiklund, Patzelt, \& Dimov, 2016) as well as their entrepreneurial orientation (Thurik, Khedhaouria, Torrès, \& Verheul, 2016).

Five studies explored different micro-level processes that help to unpack the effects of MWB by linking it to entrepreneurs' work behaviors. One experience sampling study demonstrated that negative and positive affective states influence entrepreneurs' work focus differently, by expending effort on either immediate or future-oriented tasks respectively (Foo, Uy, \& Baron, 2009). A cross-sectional multi-level study presents complementary evidence investigating goal-related affect. Positive affect, related to specific work and family goals, enabled goal realization, while entrepreneurs found it more difficult to achieve goals with a negative emotional connotation (Laguna, Alessandri, \& Caprara, 2016). A MWBrelated psychological resource ('positive orientation') moderated and facilitated these processes. In cross-sectional studies, more satisfied entrepreneurs were less likely to engage in absenteeism (absence from work because of health problems), indicating that those with high MWB are willing to expend more effort at work, despite health problems (Cocker, Martin, Scott, Venn, \& Sanderson, 2013; Lechmann \& Schnabel, 2014). However, a longitudinal study paints a more nuanced picture. Entrepreneurs' proactive work behaviors were stimulated by eudaimonic and not hedonic well-being (vigor vs. life-satisfaction, Hahn, Frese, Binnewies, \& Schmitt, 2012). 
With regard to consequences of entrepreneurs ' MWB for others, one longitudinal study identified crossover effects on the MWB of entrepreneurs' life partners (GorgievskiDuijvesteijin et al., 2000). Related longitudinal research found negative effects stemming from the stress, workload and time commitment of parental self-employment on children's MWB (Wirback, Möller, Larsson, Galanti, \& Engström, 2014). Gudmundsson (2013) offers a nuanced exploration of immigrant entrepreneurs' families describing both vicious cycles as well as empowering effects. Finally, Tobias, Mair and Barbosa-Leiker (2013) found that increases in entrepreneurs' MWB reduced their out-group prejudice (a key source of social conflict) in post-genocide Rwanda.

Dynamic relationships. Three studies in the review employed longitudinal crosslagged panel research designs and were able to test for reciprocal relationships of MWB with outcomes. Gorgievski-Duijvesteijin et al. (2000) and Gorgievski et al. (2010) noted negative downward spirals between low MWB and financial problems. Örtqvist and Wincent (2010) found reciprocal relationships between role stress and low MWB, suggesting that exhausted and dissatisfied entrepreneurs were more likely to view their work as demanding, which lead them to spiral downwards to further exhaustion and more dissatisfaction. Gudmundsson (2013) describes similar virtuous and vicious circles qualitatively in their study of immigrant entrepreneurs and their children. The feedback loops implied by such dynamic relationship are depicted by the arrows at the bottom of Figures 1 and 2 .

\section{Discussion and Future Research}

This aim of this review is to draw attention to entrepreneurs' MWB as a research area that should be positioned more centrally in management and entrepreneurship research. Through synthesizing and mapping the existing knowledge that is currently dispersed across a variety of disciplines the review provides a platform for future theoretical and empirical work on entrepreneurs' MWB. The specific findings advance our understanding of entrepreneurs' 
MWB. They systematize our knowledge about the antecedents and consequences of entrepreneurs' MWB and MWB differences among different types of entrepreneur. In particular, the review identifies novel overlooked antecedents of entrepreneurs' MWB that go beyond the work, social and personality characteristics emphasized in current research. These novel antecedents are related to entrepreneurs' motivation, human capital, firm and financial characteristics, as well as market and country context. The review also contributes by highlighting new 'social' consequences of entrepreneurs' MWB for others beyond the entrepreneur, whilst integrating findings on known consequences related to entrepreneurs' work behaviors and firm performance.

Collectively these findings provide a framework for research on entrepreneurs' MWB (Figures 1 and 2). They also point the way to evolving a new theory of entrepreneurial work and MWB by highlighting emerging themes and blind spots. This enables us to develop a more dynamic, variable, socialized, and contextualized view of entrepreneurs' MWB that takes account of the fluidity of entrepreneurs' work-life settings and the centrality of their work to their identity.

\section{From Theories for Employees to a Theory of Entrepreneurial Work and MWB}

The review revealed that current theorizing about the nature of entrepreneurs' work and MWB is underdeveloped, and thus calls for the elaboration of a dedicated theory of entrepreneurial work and MWB. This may be a surprising conclusion given the number of studies reviewed. Yet despite widespread recognition that entrepreneurs' work is 'different', existing research is dominated by models developed and validated to understand the MWB of salaried employees (e.g., the Job Demand Control Model, Karasek, 1979; Role Stress Theory, Kahn et al., 1964; Job Characteristics Model, Hackman \& Oldham, 1975; work-related social support, House, 1981) and utilizes quantitative theory-testing studies. Applying such wellestablished models to entrepreneurship was an important first step in researching 
entrepreneurs' MWB, and is reflective of the fact that much research on entrepreneurs' MWB has been conducted in fields outside of entrepreneurship.

Yet the findings of this review suggest that these models also limit our understanding of entrepreneurs' MWB. We need to significantly widen and deepen our view to truly understand entrepreneurs' work and MWB, and its many unique features. Specifically, the reviews findings highlight a wider set of antecedents and consequences of entrepreneurs' MWB; and they suggest insights and avenues for future research that instigate the building blocks of a theory of entrepreneurs' MWB. These insights pertain to the need to better understand the nature of entrepreneurs' MWB, the nature of their work, its enmeshment with their private life and identity, and the inherent trade-offs that these work and work-life settings entail. They also call for a more dynamic and contextualized approach to the unpacking of how, why, and for what new outcomes entrepreneurs' MWB may matter. Table 3 summarizes these novel insights and opportunities for future research in the form of a series of questions. I discuss them next, along with specific examples.

--- Insert Table 3 about here --

The nature of entrepreneurs' MWB. The review reveals that particular aspects of MWB (distress and hedonic well-being) have thus far been the focus of research, to the neglect of others (mental disorders and eudaimonic well-being). It finds that there are overlooked 'functionalities' of low MWB, and that a static view of MWB dominates research. This calls for a more balanced perspective of entrepreneurs' MWB, and for future work to theorize about the full range of $M W B$ indicators, their interplay and variability.

A more refined understanding of entrepreneurs' MWB would recognize that while high MWB is desirable, there may be functional aspects of low MWB that support entrepreneurs' performance. This view is inspired by studies in the review that highlight that low MWB (in the form of day-to-day negative emotions) can motivate effort with a short- 
term focus (Foo et al., 2009) and that particular symptoms of ADHD (a mental disorder) may facilitate entrepreneurial action (Wiklund et al., 2016). Such research was scarce, probably because it diverges from dominant theories that generally link positive consequences to high MWB (Fredrickson, 2013; Hobfoll, 2001; Lyubomirsky et al., 2005). Yet possible 'functionalities' of low MWB, including of symptoms of mental disorders, merit more research attention for at least two reasons. First, the review suggests that high levels of demands and feelings of stress (tense, apprehensive and occasionally overwhelmed) are ubiquitous for entrepreneurs. Second, mental disorders are on the rise. If research finds that symptoms of other disorders beyond ADHD can be functional for certain aspects of entrepreneurial action, entrepreneurship research may even help to change opinion on mental disorders.

The variability of entrepreneurs' $M W B$ is unexplored. Uncertainty is a hallmark of entrepreneurship (McMullen \& Shepherd, 2006) and implies frequent changes. This suggests that entrepreneurs' experiences may be highly variable, and may include spikes of high and low MWB. Such variability goes unnoticed by the approaches of current research, which are focused on mean levels of MWB typically aggregated across situations. No study considered variability in MWB. Thus the antecedents and consequences of possible variability of MWB and of the relative balance between well-being and distress are virtually unexplored. By focusing solely on mean-levels we may misinterpret how well entrepreneurs feel, and we may miss important drivers of entrepreneurial action. Research on affect spin, a trait related to emotion regulation, can serve as inspiration for how to conceptualize and measure MWB variability (Uy, Sun, \& Foo, 2017).

Entrepreneurs' eudaimonic well-being remains largely unexplored. This is surprising because firm performance is more likely to benefit from entrepreneurs' eudaimonic wellbeing (thriving and activated affect) than from their hedonic well-being (satisfaction and 
contentment). For instance, a focus on eudaimonic well-being entails dedicated theorizing about its predictors; this challenges researchers to consider hitherto unexplored concepts (such as character strengths and virtues) as relevant aspects of personality (Park, Peterson, \& Seligman, 2004). It would also lead to new counterintuitive research questions relating to the MWB-enhancing effects of negative states when they are in line with one's self-concept i.e. one's 'daimon' (Tamir, Schwartz, Oishi, \& Kim, 2017). For instance, the eudaimonic MWB of competitive, growth-oriented entrepreneurs may be underpinned by feelings of pride as well as anger.

Entrepreneurs consistently report high levels of hedonic well-being (e.g., job and life satisfaction), which is widely depicted as a benefit of being an entrepreneur (Benz \& Frey, 2008). Before we celebrate this finding, it seems worth unpacking the micro-foundational processes behind it. In particular, entrepreneurs' work has many features known to trigger self-justification processes so as to reduce cognitive dissonance. These processes bring one's attitudes (in the case of entrepreneurs, their satisfaction judgments) in line with past investments and choices, especially if these choices were made autonomously (Festinger, 1964). It seems likely that entrepreneurs would engage in dissonance-reducing strategies. Psychologically, they may justify the large investments of time and other personal resources that they put into their firm, and the trade-offs they are willing to make (e.g. in terms of income, leisure and family time) by seemingly deriving great satisfaction from their jobs. Entrepreneurs' self-reports of high satisfaction may thus be indicative of being locked-in to their career. Research could untangle such processes by adopting a balanced view of MWB (e.g., measuring eudaimonic MWB also), by obtaining assessments of entrepreneurs' MWB from others close to the entrepreneur, and by using objective indicators of MWB (see below).

The nature of entrepreneurs' work. Future research needs to acknowledge the variability and dynamic aspects of entrepreneurs' work. If autonomy and uncertainty are 
hallmarks of entrepreneurship, then entrepreneurs' work situations are unlikely to be static.

Thus, beyond considering aggregated mean scores of work, social, personal, firm and market resources, and stressors, what are the implications of the volatility and fluctuations in resources and stressors for entrepreneurs' MWB? Might such variation act as a stressor in its own right? No studies in the review investigated such aspects. However, the three longitudinal studies in the review, which were able to test for reciprocal relationships (Gorgievski-Duijvesteijin et al., 2000; Gorgievski 2010; Örtqvist \& Wincent, 2010), found evidence for feedback loops. This reinforces the need to pay greater attention to dynamic processes and changeability over time in understanding entrepreneur's work and their MWB. Future research should consider measures of variability and deviation of stressors and resources alongside mean scores.

The review findings reveal a range of unique stressors of entrepreneurs' work, that has not been fully recognized in past research and has yet to be theorized. Specifically, qualitative studies identified in the review suggest that past research may have missed key stressors important for entrepreneurs' MWB, such as customer and employee conflicts, uncertainty related to their actions, uncertainty in market demand, intense competition, and pressures stemming from the perceived responsibility for employees (e.g., Lechat \& Torrès, 2016; Schonfeld \& Mazzola, 2015). Moreover, the possibility that certain types of stressors can have positive effects on MWB (Podsakoff et al., 2007) was not explored in the reviewed studies. Future research could build on the challenge-hindrance stressor framework (Podsakoff et al., 2007) to help explain entrepreneurs' high levels of MWB, despite their high levels of work stress. This may explain the ambivalent effects of long working hours found in the review. When long hours signal that the business is going well and thriving (Bradly \& Roberts, 2004), they constitute a challenge stressor linking increased demands to long-term opportunities for growth, and can be associated with positive MWB. By contrast, conflicts 
with customers over delayed payments would be considered a hindrance stressor that stands in the way of entrepreneurs running their business well, with negative effects on MWB.

The review indicates that entrepreneurs' work is uniquely enmeshed with their nonwork life, to the extent that entrepreneurs could not meaningfully talk about 'work' as a separate life domain (Vaag et al., 2014). While the set of studies that investigate social support and work-family balance recognize this (Parasuraman \& Simmers, 2001), studies outside of this set typically adopt an under-socialized, individualistic perspective of the entrepreneurs in their work context. Yet one study (Berge et al., 2015) illustrated how viewing entrepreneurship in a household context adds explanatory power: it was more difficult to predict the performance-enhancing effect of providing business training and micro-finance assistance to female entrepreneurs because their husbands controlled the household finances, including the income from the wife's businesses. A related study found similar reasons for why collective, as opposed to individual, forms of female entrepreneurship were associated with higher MWB (Dutt et al., 2016). Conversely, for entrepreneurs who are the sole earners of income for their family, whether they be male or female, the perceived responsibility for their families' income and well-being may be an added strain on their MWB. In a similar vein the strain on MWB stemming from the investments of personal resources (e.g., putting up the family home as security for a business loan) go unrecognized in the reviewed studies - despite possible dramatic consequences for their MWB, such as suicide (Kameyama et al., 2011). Collectively these findings call for a more socialized view of entrepreneurs in their work-life contexts.

For entrepreneurs, work is also an expression of their personality - arguably much more so than is the case for any other occupation. The high levels of autonomy and uncertainty likely allow entrepreneurs to uniquely shape their work setting and business in line with their personality (Rauch \& Frese, 2007). This calls for models of entrepreneurial 
work and MWB to account for personality and identity alongside work, social, firm, and context characteristics. Future research could do so by more explicitly considering personsituation interactions (e.g., building on person-environment fit models, Edwards, 2008 or diathesis stress models, Zuckerman, 1999). Only three studies in the review considered such interactions (of personality with work characteristics). Beyond interactive effects, the consideration of personality also implies dynamics which are yet to be investigated empirically for entrepreneurs. Research on employees found that their personality can change over three to five years in response to work characteristics, such as high autonomy and job demands (Li, Fay, Frese, Harms, \& Gao, 2014; Wu, 2016). These characteristics are ubiquitous in entrepreneurs' work, calling for longitudinal research to explore when and how entrepreneurs' work might change their personality and with what consequences for their MWB.

Unique to research on entrepreneurs' work and MWB is the close interrelationship with the market and competitive climate within which they operate. While recognition of the importance of context for entrepreneurs' MWB is increasing in terms of how frequently it is being studied, there was no agreement among the reviewed studies on what the most relevant aspects are, how they should be captured, and through what micro-foundational processes they influence MWB. This calls for conceptual and scale development work to make sense of the diverse aspects of market and competitive context covered in the review. Such work could build on conceptualizations of market context used in strategy research (Dess \& Beard, 1984).

Unpacking the trade-offs inherent in entrepreneurs' work. The reviewed studies identified MWB trade-offs across life domains, for example, high satisfaction with work but low satisfaction with income and leisure time (e.g., Binder \& Coad, 2016). However, other trade-offs relating to entrepreneurs' work remain unexplored. 
Autonomy is widely depicted as a key resource underlying entrepreneurs' MWB and this was corroborated in nearly all studies in the review. Yet could there be too much autonomy? One qualitative study raises this possibility, and depicts entrepreneurs as struggling with navigating their freedom to choose how, what, when and with whom to work (Gelderen, 2016). Some studies imply a notion of 'fit', such that individuals who actively chose to be entrepreneurs may reap the MWB-benefits of autonomy as opposed to necessity entrepreneurs (Binder \& Coad, 2013), or that optimists thrive in settings of high autonomy and challenge (Totterdell et al., 2006). Yet research hardly explores the implications of autonomy in terms of increased accountability and feeling responsible for employees (Begley, 1994). Nor has research explored possible curvilinear effects. Might very high levels of autonomy enhance uncertainty and become overwhelming, threating and anxiety provoking - in line with the paradox of choice (Iyengar \& Lepper, 2000; Schwartz, 2004)? There are also opportunities for research to develop our understanding and chart, over time, when and how autonomy might lead to lower MWB. For instance, when it may lead entrepreneurs to overexert themselves (e.g., by pursuing every possible opportunity for growth); and, more generally how and when constraints on entrepreneurs' autonomy may arise (e.g. in response to large contracts with a dominant customers, or large investments from a particular investor, Gelderen, 2016; Reymen et al., 2015).

Two studies pointed to a possible MWB trade-off as a result of work's centrality to entrepreneurs' identity (Fisher et al., 2013; Spivack et al., 2014). The close entwinement of work and identity can lead to behaviors and feelings of obsession and addiction to work (and to 'being an entrepreneur') that are associated with low MWB. Future research should clarify the generalizability of these findings, and pinpoint when and how entrepreneurs' engagement and thriving develops into obsession and addiction. More generally, the pattern of findings (e.g. entrepreneurs' reactions to losing their job, Hetschko, 2016) points to a close link 
between identity and work for entrepreneurs in line with established research on entrepreneurial passion (Cardon, Wincent, Singh, \& Drnovsek, 2009). Yet surprisingly, no study linked passion directly to MWB, although a positive effect could be expected (Cardon et al., 2009), especially for harmonious passion on eudaimonic well-being (Vallerand, 2012).

What short- and long-term productivity and health trade-offs might there be? The review finds that entrepreneurs' work is intensely demanding and stressful, yet they seem to experience high levels of MWB - at least in the shorter-term. However, the constant exposure to high levels of numerous stressors might predispose entrepreneurs to mental disorders and diseases, and lead to low MWB in the long-term (via processes of 'allostatic load', McEwen, 2004). Indeed, one study provides related evidence consistent with this explanation for physical health (Cardon \& Patel, 2015). To avoid such long-term negative outcomes, research on work-related MWB more generally highlights the importance of recovery. Recovery research was virtually absent from the review and the declared focus of only two studies (Rau et al., 2008; Taris et al., 2008). There are therefore ample opportunities for future work. Moreover, recovery processes can offer not only a unique understanding of how entrepreneurs may be able to maintain high levels of MWB in the long-term, they may also benefit firm performance by stimulating creativity and efficiency (Weinberger, Wach, Stephan, \& Wegge, 2018; Wendsche \& Lohmann-Haislah, 2017). Understanding the nature of the recovery processes and activities entrepreneurs engage in (especially considering their time constraints) and the effects of these on MWB would be an essential part of a theory of entrepreneurial work and MWB.

Might there be a trade-off of entrepreneurs' $M W B$ for the well-being of their employees? If entrepreneurs experience high levels of MWB that are associated with greater sensitivity to recognizing opportunities (Gielnik et al., 2012), might this imply a negative effect on their employees' MWB? From a work design perspective, new opportunities are 
likely to involve new work processes, and growing businesses often struggle to hire employees at the same rate at which they expand, meaning a higher workload for and further demands on those that already work for the entrepreneur. A contrasting prediction might be derived from research on emotional contagion processes (Van Kleef, 2009), whereby the entrepreneurs' positive MWB would crossover to employees. Even though employees form an integral part of a firm, no studies in the review addressed such relationships. Thus, there are opportunities for future research to discern how and when entrepreneurs' MWB affects the MWB of their employees.

Contextualizing research on entrepreneurs' MWB. The review reinforces calls to consider heterogeneity among entrepreneurs (Davidsson, 2016) and to develop contextsensitive theories (Zahra \& Wright, 2011; Welter, 2011). It extends such calls to research on entrepreneurs' MWB. With regard to heterogeneity among entrepreneurs, the review findings highlight differences between types of entrepreneurs. Studies identified systematic variation in MWB between opportunity and necessity entrepreneurs (broadly defined). Other studies linked related concepts of intrinsic motivation and values (e.g., creativity and non-financial success) to higher MWB. There are untapped opportunities to unpack and theorize the specific profile of the MWB challenges and resources for different types of entrepreneurs. For instance, compared to self-employed sole-trader, growth-oriented employerentrepreneurs face more complex work, greater responsibility pressures for employees, and steeper competition in the market. Necessity entrepreneurs might grapple more with resource constraints. It is unclear under what circumstances and over what timeframe necessity entrepreneurs would derive performance benefits from MWB, if at all? Social entrepreneurs may be well-positioned to experience high MWB since helping others is highly meaningful work, but this may also suggest that they are at particular risk of burnout. At the same time, 
their own mental health challenges may act as a resource, helping them to recognize and develop social entrepreneurship opportunities.

Although several studies documented significant differences in entrepreneurs' $M W B$ across countries, it is by and large unclear how these country differences may be explained. This is another opportunity to build a more contextualized theory of entrepreneurs' MWB. It could explore the role of formal institutions and culture, and discern through which processes they affect entrepreneurs' MWB. For instance, two studies investigated the effect of regulation, with differing findings (Anderson \& Hughes, 2010; Kallioniemi et al., 2016) . Might it be that regulation influences entrepreneurs' MWB especially when it is perceived as unjust (e.g., entrepreneurs may feel 'punished' by a plethora of administrative rules and regulations, even though they are the ones creating jobs, often at considerable cost to their private and family life). Other formal institutions, such as the rule of law, alleviate uncertainty (Estrin, Korosteleva, \& Mickiewicz, 2013) and may thus support entrepreneurs' MWB. Culture may also shape effects. For instance, entrepreneurs' own MWB may be less important for firm performance in more collectivistic cultures, where performance will be more contingent on multiple others beyond the entrepreneur (Stephan \& Uhlaner, 2010). Moreover, the role of context in shaping the consequences of entrepreneurial MWB was unexplored in the review. Yet establishing boundary conditions as to when entrepreneurs' MWB matters for outcomes is an essential step toward a theory of entrepreneurs' MWB.

Expanding our understanding of the consequences of entrepreneurs' MWB. The consequences of entrepreneurs' MWB were the focus of far fewer studies in the review compared to research on the antecedents of MWB. There is a need to establish stronger evidence for the causal relationships from MWB to performance, and to map the intervening micro-level processes more carefully. Future research should also explore consequences of MWB beyond those studied in the review. This would allow us to develop a deeper 
understanding of why entrepreneurs' MWB matters, and would help to further legitimize MWB as an important area of entrepreneurship research. For instance, crossover effects from entrepreneurs' MWB to the MWB of their stakeholders (e.g., customers, suppliers, investors, board members) are unexplored (see Figure 2). These may take the form of emotional contagion processes as discussed above for employees. Similarly, future research could establish how and when entrepreneurs' MWB may relate to collective outcomes, such as the business climate or trust in a community.

Research existing outside of entrepreneurship provides insights on how such outcomes may evolve. Happy people are more inclined to help others through prosocial behaviors and engagement in their communities (Lyubomirsky et al., 2005). The broadening of thought repertoires (Fredrickson, 2013) and increased psychological resources (Hobfoll, 2001) associated with MWB seem to also enable more perspective taking. A single study in the review explored such a relationship for entrepreneurs, and found that higher MWB was associated with more tolerance/lower prejudice towards an outgroup (Tobias et al., 2013). This suggests intriguing links and new pathways for research on entrepreneurship, philanthropy, and social entrepreneurship whereby the everyday experiences of 'happy' entrepreneurs lead to prosocial entrepreneurial actions. This contrasts with existing explanations of, for instance, social entrepreneurship that emphasize stable prosocial traits or motivations (Stephan \& Drencheva, 2017).

To understand the consequences of entrepreneurs' MWB, future research also needs to consider theoretical perspectives beyond those dominating current research (Conservation of Resources [COR, Hobfoll, 2001], and Broaden-and-Build [Fredrickson, 2013]). This is because both theories link positive outcomes to high levels of MWB, and may lead researchers to overlook potential functional effects of low levels of MWB (as identified in the review and discussed above) as well as possible detrimental effects of high MWB. An 
example requiring new conceptual angles are the effects of entrepreneurs' MWB on ethical decision-making and transgressions. For instance, research on creative entitlement and ethical behavior (Vincent, Emich, \& Goncalo, 2013) suggests that entrepreneurs with high MWB who lead innovative firms might engage in unethical behavior, because they are likely to feel unique, 'invincible', and above the law. A the same time, entrepreneurs' work, especially feelings of time pressure, or pressures to find new contracts, may also lead to ethical transgressions (individuals are more likely to 'cut corners' when under pressure, Kouchaki \& Desai, 2015).

Towards greater plurality of research designs and methods. Research on entrepreneurs' MWB is dominated by quantitative cross-sectional self-report based theory testing studies. The dominance of any method limits the type of insights to be gained. Future research should continue the trend towards more diversity in methodological approaches.

The review suggests that the understanding of entrepreneurs' work and MWB may still be incomplete and there is scope for more theory-building work, which could be based on longitudinal qualitative studies to map the nature of MWB, its resources and demands, and the variability of resources and demands over time. There could also be a role for observational 'work shadowing' studies and ethnographic work, to investigate work as entrepreneurs encounter it day-to-day. Such research may also seek the views of others on entrepreneurs' MWB to triangulate entrepreneur self-reports.

Experience sampling studies, longitudinal and process studies seem well suited to explicating the microfoundations (Shepherd, 2015) of MWB. They facilitate unpacking the micro-level processes as well as the testing of reciprocal and dynamic relationships. This will enable constructing of a truly dynamic understanding of entrepreneurial work and MWB, and will complement the current dominance of static perspectives. 
There are opportunities to use physiological measures based on wearable technologies to circumvent possible self-report biases of entrepreneurs' MWB. Physiological measures can capture recovery, stress, and emotional micro-level processes of entrepreneurs' MWB. They can complement diary or experience sampling studies (Eatough, Shockley, \& Yu, 2016; Weinberger et al., 2018) or be incorporated in longitudinal studies (Cardon \& Patel, 2015).

Future research should pay attention to 'time'. Theorizing about the time spans over which aspects of MWB, perceptions of autonomy, social support, and other characteristics remain stable or change is essential when choosing appropriate time lags for diary, longitudinal and process studies (Dormann \& Griffin, 2015; Uy, Foo, \& Aguinis, 2010). Longitudinal research in the review varied from covering one or two years, to up to 10 years; while experience sampling studies covered time frames of days and weeks. For example, employee studies observed personality change over three and five years ( $\mathrm{Li}$ et al., 2014; Wu, 2016). However, such processes may be more fluid for entrepreneurs faced with uncertainty and enjoying autonomy and changes may be identifiable over shorter periods.

Finally, there is a role for multi-level studies to help pin-point what causes the variation of entrepreneurs' MWB across country contexts. Multi-level studies will be helpful for research relating entrepreneurs' MWB to that of their employees and other stakeholders.

\section{Conclusion}

Through taking stock of what we know, this review hopes to inspire more work on entrepreneurs' MWB and stimulate efforts to develop a theory of entrepreneurial work and MWB that highlights the uniqueness of entrepreneurship - acknowledging entrepreneurs' dynamic and fluid work-life setting, the centrality of work for their sense of identity, as well as the importance of others and their context. 


\section{References}

Ahmad, S. Z., \& Arabia, S. (2010). Stress and coping styles of entrepreneurs: A Malaysian survey. International Journal of Entrepreneurship, 14, 25-36.

Alvarez, G., \& Sinde-Cantorna, A. I. (2014). Self-employment and job satisfaction: an empirical analysis. International Journal of Manpower, 35(5), 688-702.

Anderson, N., \& Hughes, K. D. (2010). The Business of Caring: Women's Self-Employment and the Marketization of Care. Gender Work and Organization, 17(4), 381-405.

Annink, A., Gorgievski, M., \& Den Dulk, L. (2016). Financial hardship and well-being: a cross-national comparison among the European self-employed. European Journal of Work and Organizational Psychology, 25(5), 645-657.

Ashkanasy, N. M., \& Dorris, A. D. (2017). Emotions in the Workplace. Annual Review of Organizational Psychology and Organizational Behavior, 4, 67-90.

Ayala, J.-C., \& Manzano, G. (2014). The resilience of the entrepreneur. Influence on the success of the business. A longitudinal analysis. Journal of Economic Psychology, 42, $126-135$.

Backhans, M. C., \& Hemmingsson, T. (2012). Unemployment and mental health -Who is (not) affected? European Journal of Public Health, 22(3), 429-433.

Bahmannia, S., Tharan, K. B., \& Wang, J. F. (2013, March). The Impact of Economic Instability on Entrepreneurs' Well-being: Moderate Roles of Emotional Intelligence and Social Capital. In 1st International Conference on Orange Technologies (ICOT 2013), $51-54$.

Baron, R. A., Franklin, R. J., \& Hmieleski, K. M. (2016). Why Entrepreneurs Often Experience Low, Not High, Levels of Stress: The Joint Effects of Selection and Psychological Capital. Journal of Management, 42(3), 742-768.

Becker, G. (1964). Human capital: A theoretical and Empirical Analysis with Special Reference to Education. Chicago, IL: University of Chicago Press.

Begley, T. M. (1994). Expressed and suppressed anger as predictors of health complaints. Journal of Organizational Behavior, 15(6), 503-516.

Bender, K. A., \& Roche, K. (2013). Educational mismatch and self-employment. Economics of Education Review, 34, 85-95.

Benz, M., \& Frey, B. S. (2004). Being independent raises happiness at work. Swedish Economic Policy Review, 11, 95-134.

Benz, M., \& Frey, B. S. (2008). The value of doing what you like: Evidence from the selfemployed in 23 countries. Journal of Economic Behavior \& Organization, 68, 445455 .

Berge, L. I. O., Bjorvatn, K., \& Tungodden, B. (2015). Human and Financial Capital for 
Microenterprise Development: Evidence from a Field and Lab Experiment. Management Science, 61(4), 707-722.

Berglund, V., Johansson Sevä, I., \& Strandh, M. (2016). Subjective well-being and job satisfaction among self-employed and regular employees: does personality matter differently? Journal of Small Business \& Entrepreneurship, 28(1), 55-73.

Binder, M., \& Coad, A. (2013). Life satisfaction and self-employment: a matching approach. Small Business Economics, 40(4), 1009-1033.

Binder, M., \& Coad, A. (2016). How Satisfied are the Self-Employed? A Life Domain View. Journal of Happiness Studies, 17(4), 1409-1433.

Blonk, R. W. B., Brenninkmeijer, V., Lagerveld, S. E., \& Houtman, I. L. D. (2006). Return to work: A comparison of two cognitive behavioural interventions in cases of work-related psychological complaints among the self-employed. Work and Stress, 20, 129-144.

Bowling, N. A, Eschleman, K. J., \& Wang, Q. (2010). A meta-analytic examination of the relationship between job satisfaction and subjective well-being. Journal of Occupational and Organizational Psychology, 83(4), 915-934.

Bradley, D. E., \& Roberts, J. A. (2004). Self-Employment and Job Satisfaction: Investigating the Role of Self-Efficacy, Depression, and Seniority. Journal of Small Business Management, 42(1), 37-58.

Buffel, V., De Velde, S., \& Bracke, P. (2015). The mental health consequences of the economic crisis in Europe among the employed, the unemployed, and the nonemployed. Social Science Research, 54, 263-288.

Byrnes, R. T., \& Taylor, S. N. (2015). Voluntary transition of the CEO: owner CEOs' sense of self before, during and after transition. Frontiers in Psychology, 6, 1633. doi:10.3389/fpsyg.2015.01633

Cardon, M. S., Foo, M.-D., Shepherd, D., \& Wiklund, J. (2012). Exploring the Heart: Entrepreneurial Emotion Is a Hot Topic. Entrepreneurship Theory and Practice, 36(1), $1-10$.

Cardon, M. S., \& Patel, P. C. (2015). Is Stress Worth it? Stress-Related Health and Wealth Trade-Offs for Entrepreneurs. Applied Psychology, 64(2), 379-420.

Cardon, M. S., Wincent, J., Singh, J., \& Drnovsek, M. (2009). The Nature and Experience of Entrepreneurial Passion. Academy of Management Review, 34(3), 511-532.

Carree, M. A., \& Verheul, I. (2012). What Makes Entrepreneurs Happy? Determinants of Satisfaction Among Founders. Journal of Happiness Studies, 13(2), 371-387.

Clark, A., Colombier, N., \& Masclet, D. (2008). Never the same after the first time: the satisfaction of the second-generation self-employed. International Journal of Manpower, 29(7), 591-609. 
Cocker, F., Martin, A., Scott, J., Venn, A., \& Sanderson, K. (2013). Psychological Distress, Related Work Attendance, and Productivity Loss in Small-to-Medium Enterprise Owner/Managers. International Journal of Environmental Research and Public Health, 10(10), 5062-5082.

Cohidon, C., Diène, E., Carton, M., Fatras, J.-Y., Goldberg, M., \& Imbernon, E. (2009). Mental health of workers in Toulouse 2 years after the industrial AZF disaster: first results of a longitudinal follow-up of 3,000 people. Social Psychiatry and Psychiatric Epidemiology, 44(9), 784-791.

Crawford, A., \& Naar, J. (2016). Exit Planning of Lifestyle and Profit-Oriented Entrepreneurs in Bed and Breakfasts. International Journal of Hospitality \& Tourism Administration, 17(3), 260-285.

Cuellar-Molina, D., Maria Lucia-Casademunt, A., \& Mercedes Garcia-Cabrera, A. (2015). Institutional environment and job well-being on the governance of the tourism industry: a European study. Pasos-Revista de Turismo Y Patrimonio Cultural, 13(6), 1387-1399.

Cueto, B., \& Pruneda, G. (2017). Job Satisfaction of Wage and Self-Employed Workers. Do Job Preferences Make a Difference? Applied Research in Quality of Life, 12(1), 103123.

D’Angelo, S., Coggon, D., Harris, E. C., Linaker, C., Sayer, A. A., Gale, C. R., ... Palmer, K. T. (2016). Job dissatisfaction and the older worker: Baseline findings from the Health and Employment after Fifty study. Occupational and Environmental Medicine, 73, 512-519.

Davidsson, P. (2016). A “Business Researcher" View on Opportunities for Psychology in Entrepreneurship Research. Applied Psychology, 65(3), 628-636.

Dawson, C. (2017). Financial Optimism and Entrepreneurial Satisfaction. Strategic Entrepreneurship Journal, 11, 171-194.

De Mel, S., McKenzie, D., \& Woodruff, C. (2008). Mental health recovery and economic recovery after the tsunami: High-frequency longitudinal evidence from Sri Lankan small business owners. Social Science \& Medicine, 66(3), 582-595.

Dess, G. G., \& Beard, D. W. (1984). Dimensions of Organizational Task Environments. Administrative Science Quarterly, 29(1), 52-73.

Diener, E., Suh, E. M., Lucas, R. E., \& Smith, H. L. (1999). Subjective well-being: Three decades of progress. Psychological Bulletin, 125(2), 276-302.

Dormann, C., \& Griffin, M. A. (2015). Optimal Time Lags in Panel Studies. Psychological Methods, 20(4), 489- 505.

Drnovšek, M., Örtqvist, D., \& Wincent, J. (2010). The effectiveness of coping strategies used by entrepreneurs and their impact on personal well-being and venture performance.

Proceedings of Rijeka Faculty of Economics, 28(2), 193-220. 
Dufouil, C., Pereira, E., Chêne, G., Glymour, M. M., Alpérovitch, A., Saubusse, E., ... Forette, F. (2014). Older age at retirement is associated with decreased risk of dementia. European Journal of Epidemiology, 29(5), 353-361.

Dutt, A., Grabe, S., \& Castro, M. (2016). Exploring Links between Women's Business Ownership and Empowerment among Maasai Women in Tanzania. Analyses of Social Issues and Public Policy, 16, 363-386.

Eatough, E., Shockley, K., \& Yu, P. (2016). A Review of ambulatory health data collection methods for employee experience sampling research. Applied Psychology, 65, 322-354.

Edwards, J. R. (2008). Person-Environment Fit in Organizations: An Assessment of Theoretical Progress. Academy of Management Annals, 2, 167-230.

Estrin, S., Korosteleva, J., \& Mickiewicz, T. (2013). Which institutions encourage entrepreneurial growth aspirations? Journal of Business Venturing, 28(4), 564-580.

European Commission (2016). Beyond GDP: Measuring progress, true wealth, and wellbeing. Retrieved September 25, 2016, from http://ec.europa.eu/environment/beyond_gdp/index_en.html

Fernet, C., Torrès, O., Austin, S., \& St-Pierre, J. (2016). The psychological costs of owning and managing an SME: Linking job stressors, occupational loneliness, entrepreneurial orientation, and burnout. Burnout Research, 3(2), 45-53.

Festinger, L. (1964). Conflict, decision, and dissonance. Conflict decision and dissonance. Stanford: Stanford University Press.

Fisher, R., Maritz, A., \& Lobo, A. (2013). Obsession in Entrepreneurs - Towards a Conceputalisation. Entrepreneurship Research Journal, 3(2), 207-237.

Foo, M.-D. (2011). Emotions and Entrepreneurial Opportunity Evaluation. Entrepreneurship Theory and Practice, 35(2), 375-393.

Foo, M.-D., Uy, M. A., \& Baron, R. A. (2009). How Do Feelings Influence Effort? An Empirical Study of Entrepreneurs' Affect and Venture Effort. Journal of Applied Psychology, 94, 1086-1094.

Ford, M. T., Matthews, R. A., Wooldridge, J. D., Mishra, V., Kakar, U. M., \& Strahan, S. R. (2014). How do occupational stressor-strain effects vary with time? A review and metaanalysis of the relevance of time lags in longitudinal studies. Work \& Stress, 28(1), 930 .

Fredrickson, B. L. (2001). The Role of Positive Emotions in Positive Psychology. The Broaden-and-Build Theory of Positive Emotions. American Psychologist, 56(3), 218 226.

Fredrickson, B. L. (2013). Positive Emotions Broaden and Build. Advances in Experimental Social Psychology, 47, 1-53. 
Frese, M., \& Gielnik, M. M. (2014). The psychology of entrepreneurship. Annual Review of Organizational Psychology and Organizational Behavior, 1, 413-438.

Gartner, W. B. (1989). "Who is an Entrepreneur?" Is the Wrong Question. Entrepreneurship: Theory and Practice, 12(4), 47-67.

Gielnik, M., Zacher, H., \& Frese, M. (2012). Focus on opportunities as a mediator of the relationship between business owners' age and venture growth. Journal of Business Venturing, 27(1), 127-142.

Gimeno, J., Folta, T. B., Cooper, A. C., \& Woo, C. Y.,(1997). Survival of the Fittest? Entrepreneurial Human Capital and the Persistence of Underperforming Firms. Administrative Science Quarterly, 42(4), 750-783.

Gorgievski-Duijvesteijin, M., Giesen, C., \& Bakker, A. (2000). Financial problems and health complaints among farm couples: Results of a 10-yr follow-up study. Journal of Occupational Health Psychology, 5(3), 359-373.

Gorgievski, M., Moriano, J.A., \& Bakker, A. B. (2014). Relating work engagement and workaholism to entrepreneurial performance. Journal of Managerial Psychology, 29(2), 106-121.

Gorgievski, M., Bakker, A., Schaufeli, W., Van der Veen, H., \& Giesen, C. (2010). Financial problems and psychological distress: Investigating reciprocal effects among business owners. Journal of Occupational and Organizational Psychology, 83, 513-530.

Gorgievski, M., \& Stephan, U. (2016). Advancing the Psychology of Entrepreneurship: A Review of the Psychological Literature and an Introduction. Applied Psychology, 65(3), 437-468.

Gudmundsson, G. (2013). Quality Spirals and Vicious Circles among Children of Immigrant Entrepreneurs: How Immigrant Entrepreneurs' Resources are Remoulded by the Second Generation. Young, 21, 173-191.

Gunnarsson, K., Vingard, E., \& Josephson, M. (2007). Self Rated Health and Working Conditions of Small-Scale Enterprisers in Sweden. Industrial Health, 45(6), 775-780.

Hackman, J. R., \& Oldham, G. R. (1975). Development of the Job Diagnostic Survey. Journal of Applied Psychology, 60(2), 159-170.

Hahn, V. C., Frese, M., Binnewies, C., \& Schmitt, A. (2012). Happy and Proactive? The Role of Hedonic and Eudaimonic Well-Being in Business Owners' Personal Initiative. Entrepreneurship Theory and Practice, 36(1), 97-114.

Hausser, J. A., Mojzisch, A., Niesel, M., \& Schulz-Hardt, S. (2010). Ten years on: A review of recent research on the Job Demand-Control (-Support) model and psychological wellbeing. Work \& Stress, 24(1), 1-35.

Hébert, R. F., \& Link, A. N. (1982). The entrepreneurs: Mainstream views and radical critiques. New York: Praeger. 
Hessels, J., Rietveld, C. A., \& Van der Zwan, P. (2017). Self-employment and work-related stress: The mediating role of job control and job demand. Journal of Business Venturing, 32(2), 178-196.

Hetschko, C. (2016). On the misery of losing self-employment. Small Business Economics, $47(2), 461-478$.

Hmieleski, K. M., \& Corbett, A. C. (2008). The contrasting interaction effects of improvisational behavior with entrepreneurial self-efficacy on new venture performance and entrepreneur work satisfaction. Journal of Business Venturing, 23(4): 482-496.

Hobfoll, S. E. (2001). The Influence of Culture, Community, and the Nested-Self in the Stress Process: Advancing Conservation of Resources Theory. Applied Psychology, $50(3), 337-421$.

House, J. S. (1981). Work stress and social support. Reading, MA: Addison-Wesley.

Humphrey, S. E., Nahrgang, J. D., \& Morgeson, F. P. (2007). Integrating motivational, social, and contextual work design features: a meta-analytic summary and theoretical extension of the work design literature. Journal of Applied Psychology, 92(5), 13321356.

Hundley, G. (2001). Why and When Are the Self-Employed More Satisfied with Their Work? Industrial Relations, 40(2), 293-316.

Hytti, U., Kautonen, T., \& Akola, E. (2013). Determinants of job satisfaction for salaried and self-employed professionals in Finland. International Journal of Human Resource Management, 24(10), 2034-2053.

Iyengar, S. S., \& Lepper, M. R. (2000). When choice is demotivating: Can one desire too much of a good thing? Journal of Personality and Social Psychology, 79(6), 995-1005.

Jiang, C., Lu, L., \& Lu, J. J. (2017). Socioeconomic factors affecting the job satisfaction levels of self-employed container truck drivers: a case study from Shanghai Port. Maritime Policy \& Management, 44(5), 641-656.

Johansson Sevä, I., Larsson, D., \& Strandh, M. (2016). The prevalence , characteristics and well-being of " necessity" self-employed and "latent" entrepreneurs: findings from Sweden. International Journal of Entrepreneurship and Small Business, 28(1), 5877.

Johansson Sevä, I., Vinberg, S., Nordenmark, M., \& Strandh, M. (2016). Subjective wellbeing among the self-employed in Europe: macroeconomy, gender and immigrant status. Small Business Economics, 46(2), 239-253.

Johnson, S. L., Freeman, M. A., \& Staudenmaier, P. J. (2015). Manic tendencies are not related to being an entrepreneur, intending to become an entrepreneur, or succeeding as an entrepreneur. Journal of Affective Disorders, 173, 154-158. 
Kadowaki, H., Kayano, T., Tobinaga, T., Tsusumi, A., Watari, M., \& Makita, K. (2016). Analysis of factors associated with hesitation to restart farming after depopulation of animals due to 2010 foot-and-mouth disease epidemic in Japan. Journal of Veterinary Medical Science, 78(8), 1251-1259.

Kahn, R. L., Wolfe, D. M., Quinn, R. P., Snoek, J. D., \& Rosenthal, R. A. (1964). Organizational Stress: Studies in Role Conflict and Ambiguity. American Sociological Review, 30(4), 620.

Kahneman, D., Diener, E., \& Schwarz, N. (1999). Well-being: Foundations of hedonic psychology. New York: Russel Sage Foundation.

Kallioniemi, M. K., Simola, A., Kaseva, J., \& Kymäläinen, H.-R. (2016). Stress and Burnout Among Finnish Dairy Farmers. Journal of Agromedicine, 21(3), 259-268.

Kallioniemi, M. K., Simola, K. A. J., Kymäläinen, H.-R., Vesala, H. T., \& Louhelainen, J. K. (2009). Mental symptoms among Finnish farm entrepreneurs. Annuals of Agricultural Environmental Medicine, 16, 159-168.

Kameyama, A., Matsumoto, T., Katsumata, Y., Akazawa, M., Kitani, M., Hirokawa, S., \& Takeshima, T. (2011). Psychosocial and psychiatric aspects of suicide completers with unmanageable debt: A psychological autopsy study. Psychiatry and Clinical Neurosciences, 65(6), 592-595.

Karasek, R. A. (1979). Job Demands, Job Decision Latitude, and Mental Strain: Implications for Job Redesign. Administrative Science Quarterly, 24(2), 285-308.

Karasek, R. A., \& Theorell, T. (1990). Healthy work: stress, productivity, and the reconstruction of working life. New York, NY: Basic Books.

Karlan, D., \& Zinman, J. (2011). Microcredit in Theory and Practice: Using Randomized Credit Scoring for Impact Evaluation. Science, 332(6035), 1278-1284.

Kautonen, T., Hytti, U., Boegenhold, D., \& Heinonen, J. (2012). Job satisfaction and retirement age intentions in Finland Self-employed versus salary earners. International Journal of Manpower, 33(4), 424-440.

Kouchaki, M., \& Desai, S. D. (2015). Anxious, threatened, and also unethical: How anxiety makes individuals feel threatened and commit unethical acts. Journal of Applied Psychology, 100(2), 360-375.

Kwon, I., \& Sohn, K. (2017). Job dissatisfaction of the self-employed in Indonesia. Small Business Economics, 49(1), 233-249.

Laguna, M., Alessandri, G., \& Caprara, G. V. (2016). Personal Goal Realisation in Entrepreneurs: A Multilevel Analysis of the Role of Affect and Positive Orientation. Applied Psychology, 65(3), 587-604.

Laguna, M., Razmus, W., \& Żaliński, A. (2017). Dynamic relationships between personal resources and work engagement in entrepreneurs. Journal of Occupational and 
Organizational Psychology, 90(2), 248-269.

Lange, T. (2012). Job satisfaction and self-employment: autonomy or personality? Small Business Economics, 38(2), 165-177.

Lazarus, R. S., \& Folkman, S. (1984). Stress, appraisal, and coping. New York: Springer.

Lechat, T., \& Torrès, O. (2016). Exploring Negative Affect in Entrepreneurial Activity: Effects on Emotional Stress and Contribution to Burnout. In N. M. Ashkanasy, C. E. J. Hartel, \& W. J. Zerbe (Eds.), Emotions and Organizational Governance (Vol. 12, pp. 69-99). Emerald.

Lechat, T., \& Torrès, O. (2017). Stressors and satisfactors in entrepreneurial activity: an event-based, mixed methods study predicting small business owners' health.

International Journal of Entrepreneurship and Small Business, 32(4), 537-569.

Lechmann, D. S. J., \& Schnabel, C. (2014). Absence from Work of the Self-Employed: A Comparison with Paid Employees. Kyklos, 67(3), 368-390.

Li, W.-D., Fay, D., Frese, M., Harms, P. D., \& Gao, X. Y. (2014). Reciprocal relationship between proactive personality and work characteristics: A latent change score approach. Journal of Applied Psychology, 99(5), 948-965.

Loewe, N., Araya-Castillo, L., Thieme, C., \& Batista-Foguet, J.M. (2015). Self-employment as a moderator between work and life satisfaction. Academia-Revista Latinoamericana de Administracion, 28(2), 213-226.

Luchman, J. N., \& González-Morales, M. G. (2013). Demands, control, and support: A metaanalytic review of work characteristics interrelationships. Journal of Occupational Health Psychology, 18(1), 37-52.

Lyubomirsky, S., King, L., \& Diener, E. (2005). The benefits of frequent positive affect: Does happiness lead to success? Psychological Bulletin, 131(6), 803-855.

McEwen, B. S. (1998). Stress, adaptation, and disease. Allostasis and allostatic load. Annals of the New York Academy of Sciences, 840, 33-44.

McEwen, B. S. (2004). Protection and Damage from Acute and Chronic Stress: Allostasis and Allostatic Overload and Relevance to the Pathophysiology of Psychiatric Disorders. Annals of the New York Academy of Sciences, 1032, 1-7.

McLellan, K.-L., \& Uys, K. (2009). Balancing dual roles in self-employed women: an exploratory study. SA Journal of Industrial Psychology, 35(1), 21-30.

McMullen, J. S., \& Shepherd, D. A. (2006). Entrepreneurial action and the role of uncertainty in the theory of the entrepreneur. Academy of Management Review, 31(1), 132-152.

Millán, J. M., Hessels, J., Thurik, R., \& Aguado, R. (2013). Determinants of job satisfaction: A European comparison of self-employed and paid employees. Small Business Economics, 40(3), 651-670. 
Morrison, K. A. (1997). Personality correlates of the five-factor model for a sample of business owners/managers: Associations with scores on self-monitoring, type A behavior, locus of control, and subjective well-being. Psychological Reports, 80(1), 255-272.

Müller, G. F., \& Gappisch, C. (2005). Personality types of entrepreneurs. Psychological Reports, 96(3), 737-746.

Naudé, W., Amorós, J. E., \& Cristi, O. (2014). "Surfeiting, the appetite may sicken": entrepreneurship and happiness. Small Business Economics, 42(3), 523-540.

Nguyen, H., \& Sawang, S. (2016). Juggling or Struggling? Work and Family Interface and Its Buffers among Small Business Owners. Entrepreneurship Research Journal, 6(2), 207-246.

Obschonka, M., \& Silbereisen, R. K. (2015). The effects of work-related demands associated with social and economic change on psychological well-being: A study of employed and self-employed individuals. Journal of Personnel Psychology, 14(1), 8-16.

Örtqvist, D., Drnovsek, M., \& Wincent, J. (2007). Entrepreneurs' coping with challenging role expectations. Baltic Journal of Management, 2(3), 288-304.

Örtqvist, D., \& Wincent, J. (2010). Role stress, exhaustion, and satisfaction: A cross-lagged structural equation modeling approach supporting Hobfoll's loss spirals. Journal of Applied Social Psychology, 40(6), 1357-1384.

Parasuraman, S., \& Simmers, C. A. (2001). Type of employment, work-family conflict and well-being: a comparative study. Journal of Organizational Behavior, 22, 551-568.

Park, N., Peterson, C., \& Seligman, M. E. P. (2004). Strengths of character and well-being. Journal of Social and Clinical Psychology, 23(5), 603-619.

Parker, S. K. (2014). Beyond motivation: Job and work design for development, health, ambidexterity, and more. Annual Review of Psychology, 65, 661-691.

Parslow, R. A., Jorm, A. F., Christensen, H., Rodgers, B., Strazdins, L., \& D’Souza, R. M. (2004). The associations between work stress and mental health: A comparison of organizationally employed and self-employed workers. Work and Stress, 18(3), 231244.

Patel, P. C., \& Thatcher, S. M. B. (2014). Sticking It Out: Individual Attributes and Persistence in Self-Employment. Journal of Management, 40(7), 1932-1979.

Patzelt, H., \& Shepherd, D. A. (2011). Negative emotions of an entrepreneurial career: Selfemployment and regulatory coping behaviors. Journal of Business Venturing, 26(2), 226-238.

Payne, S. C., \& Webber, S. S. (2006). Effects of service provider attitudes and employment status on citizenship behaviors and customers' attitudes and loyalty behavior. Journal of 
Applied Psychology, 91, 365-378.

Petrescu, M. (2016). Self-Employed Individuals with and without Employees: Individual, Social and Economic Level Differences. International Review of Entrepreneurship, 14(3), 289-312.

Podsakoff, N. P., LePine, J. A., \& LePine, M. A. (2007). Differential challenge stressorhindrance stressor relationships with job attitudes, turnover intentions, turnover, and withdrawal behavior: a meta-analysis. Journal of Applied Psychology, 92(2), 438.

Pollack, J. M., Vanepps, E. M., \& Hayes, A. F. (2012). The moderating role of social ties on entrepreneurs' depressed affect and withdrawal intentions in response to economic stress. Journal of Organizational Behavior, 33(6), 789-810.

Prottas, D. J., \& Thompson, C. A. (2006). Stress, satisfaction, and the work-family interface: A comparison of self-employed business owners, independents, and organizational employees. Journal of Occupational Health Psychology, 11, 366-378.

Przepiorka, A. M. (2017). Psychological Determinants of Entrepreneurial Success and LifeSatisfaction. Current Psychology, 36(2), 304-315.

Rahim, A. (1996). Stress, strain, and their moderators: An empirical comparison of entrepreneurs and managers. Journal of Small Business Management, 34(1), 46-58.

Rau, R., Hoffmann, K., Metz, U., Richter, P. G., Roesler, U., \& Stephan, U. (2008). Gesundheitsrisiken bei Unternehmern. Zeitschrift fuer Arbeits- und Organisationspsychologie, 52(3), 115-125.

Rauch, A., \& Frese, M. (2007). Let's put the person back into entrepreneurship research: A meta-analysis on the relationship between business owners' personality traits, business creation, and success. European Journal of Work and Organizational Psychology, 16(4), 353-385.

Real, E., Jover, L., Verdaguer, R., Griera, A., Segalàs, C., Alonso, P., ... Menchón, J. M. (2016). Factors Associated with Long-Term Sickness Absence Due to Mental Disorders: A Cohort Study of 7.112 Patients during the Spanish Economic Crisis. PLoS ONE, 11(1), e0146382. doi:10.1371/journal.pone.0146382

Reymen, I. M. M. J., Andries, P., Berends, H., Mauer, R., Stephan, U., \& Van Burg, E. (2015). Understanding Dynamics of Strategic Decision Making in Venture Creation: A Process Study of Effectuation and Causation. Strategic Entrepreneurship Journal, 9(4), 351-379.

Rietveld, C. A., Bailey, H., Hessels, J., \& Van der Zwan, P. (2016). Health and entrepreneurship in four Caribbean Basin countries. Economics \& Human Biology, 21, 84-89.

Rietveld, C. A., Hessels, J., \& Van der Zwan, P. (2015). The stature of the self-employed and its relation with earnings and satisfaction. Economics \& Human Biology, 17, 59-74. 
Roccas, S., Sagiv, L., Schwartz, S. H., \& Knafo, A. (2002). The Big Five personality factors and personal values. Personality and Social Psychology Bulletin, 28(6), 789-801.

Roche, M., Haar, J. M., \& Luthans, F. (2014). The role of mindfulness and psychological capital on the well-being of leaders. Journal of Occupational Health Psychology, 19(4), 476-489.

Ryan, R. M., \& Deci, E. L. (2001). On happiness and human potentials: A review of research on hedonic and eudaimonic well-being. Annual Review of Psychology, 52(1), 141-166.

Ryan, R. M., \& Deci, E. L. (2000). Self-determination theory and the facilitation of intrinsic motivation, social development, and well-being. American Psychologist, 55(1), 68-78.

Ryff, C. D. (2017). Eudaimonic well-being, inequality, and health: Recent findings and future directions. International Review of Economics, 64(2), 159-178.

Saarni, S. I., Saarni, E. S., \& Saarni, H. (2008). Quality of life, work ability, and self employment: a population survey of entrepreneurs, farmers, and salary earners. Occupational and Environmental Medicine, 65(2), 98-103.

Schjoedt, L. (2009). Entrepreneurial Job Characteristics: An Examination of Their Effect on Entrepreneurial Satisfaction. Entrepreneurship Theory and Practice, 33(3), 619-644.

Schneck, S. (2014). Why the self-employed are happier: Evidence from 25 European countries. Journal of Business Research, 67(6), 1043-1048.

Schneider, B. (1987). The People Make the Place. Personnel Psychology, 40(3), 437-453.

Schonfeld, I. S., \& Mazzola, J. J. (2015). A qualitative study of stress in individuals selfemployed in solo businesses. Journal of Occupational Health Psychology, 20(4), 501513.

Schwartz, B. (2004). The paradox of choice: why more is less. NY: Harper Collins.

Shepherd, D. A. (2015). Party On! A call for entrepreneurship research that is more interactive, activity based, cognitively hot, compassionate, and prosocial. Journal of Business Venturing, 30(4), 489-507.

Shepherd, D. A., Wiklund, J., \& Haynie, J. M. (2009). Moving forward: Balancing the financial and emotional costs of business failure. Journal of Business Venturing, 24(2), 134-148.

Shepherd, D. A., \& Patzelt, H. (2015). The "heart" of entrepreneurship: The impact of entrepreneurial action on health and health on entrepreneurial action. Journal of Business Venturing Insights, 4, 22-29.

Sherman, C. L., Randall, C., \& Kauanui, S. K. (2016). Are you happy yet? Entrepreneurs' subjective well-being. Journal of Management, Spirituality \& Religion, 13(1), 7-23.

Sikora, J., \& Saha, L. J. (2009). Vocational education, self-employment and burnout among 
Australian workers. Australian Journal of Social Issues, 44(1), 55-72.

Sonnentag, S., \& Fritz, C. (2015). Recovery from job stress: The stressor-detachment model as an integrative framework. Journal of Organizational Behavior, 36(S1), S72-S103.

Sörensson, A., \& Dalborg, C. (2017). Female entrepreneurs in nature-based businesses: working conditions, well-being, and everyday life situation. Society, Health \& Vulnerability, 8(1), 1306905. doi: 10.1080/20021518.2017.1306905

Spivack, A. J., McKelvie, A., \& Haynie, J. M. (2014). Habitual entrepreneurs: Possible cases of entrepreneurship addiction? Journal of Business Venturing, 29(5), 651-667.

Stephan, U., \& Drencheva, A. (2017). The Person in Social Entrepreneurship: A Systematic Review of Research on the Social Entrepreneurial Personality. In \& T. K. G. Ahmetoglu, T. Chamorro-Premuzic, B. Klinger (Ed.), The Wiley Handbook of Entrepreneurship (pp. 205-230). Chichester: Wiley.

Stephan, U., \& Uhlaner, L. M. (2010). Performance-based vs socially supportive culture: A cross-national study of descriptive norms and entrepreneurship. Journal of International Business Studies, 41(8), 1347-1364.

Stephan, U., \& Roesler, U. (2010). Health of entrepreneurs versus employees in a national representative sample. Journal of Occupational and Organizational Psychology, 83(3), $717-738$.

Stiglitz, J. E., Sen, A., \& Fitoussi, J.-P. (2009). Report by the Commission on the Measurement of Economic Performance and Social Progress. Paris: Commission on the Measurement of Economic Performance and Social Progress.

Tamir, M., Schwartz, S. H., Oishi, S., \& Kim, M. Y. (2017). The Secret to Happiness: Feeling Good or Feeling Right? Journal of Experimental Psychology: General, 146(10):1448-1459.

Taris, T. W., Geurts, S. A. E., Schaufeli, W. B., Blonk, R. W. B., \& Lagerveld, S. E. (2008). All day and all of the night: The relative contribution of two dimensions of workaholism to well-being in self-employed workers. Work \& Stress, 22(2), 153-165.

Tetrick, L. E., Slack, K. J., Da Silva, N., \& Sinclair, R. R. (2000). A comparison of the stressstrain process for business owners and nonowners: differences in job demands, emotional exhaustion, satisfaction, and social support. Journal of Occupational Health Psychology, 5, 464-476.

Thompson, C. A., Kopelman, R. E., \& Schriesheim, C. A. (1992). Putting all one's eggs in the same basket: A comparison of commitment and satisfaction among self- and organizationally employed men. Journal of Applied Psychology, 77(5), 738-743.

Thurik, R., Khedhaouria, A., Torrès, O., \& Verheul, I. (2016). ADHD Symptoms and Entrepreneurial Orientation of Small Firm Owners. Applied Psychology, 65, 568-586.

Tobias, J. M., Mair, J., \& Barbosa-Leiker, C. (2013). Toward a theory of transformative 
entrepreneuring: Poverty reduction and conflict resolution in Rwanda's entrepreneurial coffee sector. Journal of Business Venturing, 28(6), 728-742.

Torp, S., Nielsen, R. A., Gudbergsson, S. B., \& Dahl, A. A. (2012). Worksite adjustments and work ability among employed cancer survivors. Supportive Care in Cancer, 20(9), 2149-2156.

Torp, S., Syse, J., Paraponaris, A., \& Gudbergsson, S. (2017). Return to work among selfemployed cancer survivors. Journal of Cancer Survivorship, 11(2), 189-200.

Totterdell, P., Wood, S., \& Wall, T. (2006). An intra-individual test of the demands-control model: A weekly diary study of psychological strain in portfolio workers. Journal of Occupational and Organizational Psychology, 79, 63-84.

Tranfield, D., Denyer, D., \& Smart, P. (2003). Towards a methodology for developing evidence-informed management knowledge by means of systematic review. British Journal of Management, 14(3), 207-222.

Ugwu, D. I., Orjiakor, C. T., Enwereuzor, I. K., Onyedibe, C. C., \& Ugwu, L. I. (2016). Business-life balance and wellbeing: Exploring the lived experiences of women in a low-to-middle income country. International Journal of Qualitative Studies on Health and Well-being, 11(1), 30492. doi: 10.3402/qhw.v11.30492

Uy, M. A., Foo, M.-D., \& Aguinis, H. (2010). Using Experience Sampling Methodology to Advance Entrepreneurship Theory and Research. Organizational Research Methods, 13(1), 31-54.

Uy, M. A., Foo, M.-D., \& Song, Z. (2013). Joint effects of prior start-up experience and coping strategies on entrepreneurs' psychological well-being. Journal of Business Venturing, 28(5), 583-597.

Uy, M. A., Sun, S., \& Foo, M.-D. (2017). Affect spin, entrepreneurs' well-being, and venture goal progress: The moderating role of goal orientation. Journal of Business Venturing, 32(4), 443-460.

Vaag, J., Giæver, F., \& Bjerkeset, O. (2014). Specific demands and resources in the career of the Norwegian freelance musician. Arts \& Health, 6(3), 205-222.

Vallerand, R. J. (2012). The role of passion in sustainable psychological well-being. Psychology of Well-Being: Theory, Research and Practice, 2(1), 1.

Van Gelderen, M. (2016). Entrepreneurial Autonomy and its Dynamics. Applied Psychology, 65(3), 541-567.

Van Kleef, G. A. (2009). How Emotions Regulate Social Life: The Emotions as Social Information (EASI) Model . Current Directions in Psychological Science , 18, 184 188.

Van Praag, C. M., \& Versloot, P. H. (2008). The Economic Benefits and Costs of Entrepreneurship: A Review of the Research. Foundations and Trends in 
Entrepreneurship, 4(2), 65-154.

Van den Heuvel, A., \& Wooden, M. (1997). Self-employed contractors and job satisfaction. Journal of Small Business Management, 35(3), 11-20.

Vesala, H., \& Tuomivaara, S. (2015). Slowing work down by teleworking periodically in rural settings? Personnel Review, 44(4), 511-528.

Vincent, L. C., Emich, K. J., \& Goncalo, J. A. (2013). Stretching the Moral Gray Zone. Psychological Science, 24(4), 595-599.

Wach, D., Stephan, U., \& Gorgievski, M. (2016). More than money: Developing an integrative multi-factorial measure of entrepreneurial success. International Small Business Journal, 34(8), 1098-1121.

Wallis, A., \& Dollard, M. F. (2008). Local and global factors in work stress - the Australian dairy farming examplar. Scandinavian Journal of Work Environment \& Health, 6, 6674.

Warr, P. (2013). How to think about and measure psychological wellbeing. In M. Wang, R. R. Sinclair, \& L. E. Tetrick (Eds.), Research methods in occupational health psychology, Measurement, desing and data analysis (pp. 76-90). New York: Routledge.

Weinberger, E., Wach, D., Stephan, U., \& Wegge, J. (2018). Having a creative day: Understanding entrepreneurs' daily idea generation through a recovery lens. Journal of Business Venturing, 33(1), 1-19.

Welter, F. (2011). Contextualizing entrepreneurship - conceptual challenges and ways forward. Entrepreneurship theory and Practice, 35(1), 165-184.

Wendsche, J., Lohmann-Haislah, A., (2017). A meta-analysis on antecedants and outcomes of detachment from work. Frontiers in Psychology, 7, 2072. Doi:

10.3389/fpsyg.2016.02072.

Wiklund, J., Patzelt, H., \& Dimov, D. (2016). Entrepreneurship and psychological disorders: How ADHD can be productively harnessed. Journal of Business Venturing Insights, 6 , 14-20.

Williams, T. A., \& Shepherd, D. A. (2016). Victim entrepreneurs doing well by doing good: Venture creation and well-being in the aftermath of a resource shock. Journal of Business Venturing, 31(4), 365-387.

Wincent, J., \& Örtqvist, D. (2009). A Comprehensive Model of Entrepreneur Role Stress Antecedents and Consequences. Journal of Business and Psychology, 24, 225-243.

Wincent, J., Örtqvist, D., \& Drnovsek, M. (2008). The entrepreneur's role stressors and proclivity for a venture withdrawal. Scandinavian Journal of Management, 24, 232 246. 
Wirback, T., Möller, J., Larsson, J.-O., Galanti, M. R., \& Engström, K. (2014). Social factors in childhood and risk of depressive symptoms among adolescents - a longitudinal study in Stockholm, Sweden. International Journal for Equity in Health, 13(1), 96.

World Health Organization. (2014). Mental health: A state of well-being. Retrieved September 25, 2016, from http://www.who.int/features/factfiles/mental_health/en/

Wu, C.-H. (2016). Personality change via work: A job demand-control model of Big-five personality changes. Journal of Vocational Behavior, 92, 157-166.

Zahra, S. A., \& Wright, M. (2011). Entrepreneurship's Next Act. Academy of Management Perspectives, 25(4), 67-83.

Zbierowski, P. (2014). Well-being of entrepreneurs - International comparison based on GEM data. Journal of Positive Management, 5(4), 89-100.

Zhang, C., Chen, C., Li, J., \& Zhou, X. (2016, September). Entrepreneurs' failure times and their well-being, moderated by entrepreneurial environment. Portland International Conference on Management of Engineering and Technology (PICMET 2016), 13581364.

Zuckerman, M. (1999). Diathesis-stress models. In M. Zuckerman (ed.) Vulnerability to psychopathology: A biosocial model. (pp. 3-23). Washington: American Psychological Association. 
Table 1. Overview of Review Findings on the Antecedents of Entrepreneurs' Mental Health and WellBeing (MWB)

\begin{tabular}{|c|c|c|c|c|c|c|c|}
\hline \multirow[t]{2}{*}{ Antecedent } & \multicolumn{4}{|c|}{ Effect on MWB } & \multirow{2}{*}{$\begin{array}{l}\text { Total } \\
\text { N of } \\
\text { studies }\end{array}$} & \multirow{2}{*}{$\begin{array}{l}\text { N stronger } \\
\text { research } \\
\text { designs } 1 \\
\end{array}$} & \multirow{2}{*}{ Notes } \\
\hline & + & 0 & - & Other & & & \\
\hline \multicolumn{5}{|c|}{ Work characteristics ${ }^{2}$} & 49 & 13 & \\
\hline \multicolumn{8}{|l|}{ Resources } \\
\hline Autonomy & $18^{*}$ & $2 * *$ & & & 20 & 4 & $\begin{array}{l}\text { *In Parslow et al. (2004) autonomy had } \\
\text { a positive effect only for self-employed } \\
\text { women, not for self-employed men; } \\
\text { **see manuscript text }\end{array}$ \\
\hline Time flexibility & 3 & $1^{*}$ & & & 4 & & $\begin{array}{l}\text { *No effect when considered alongside } \\
\text { autonomy in Parasuraman and Simmers } \\
\text { (2001), but additional positive effect } \\
\text { alongside autonomy in Hundley (2001) } \\
\text { and Alvarez and Sinde-Cantorna (2014) }\end{array}$ \\
\hline Skill utilization & 2 & $1^{*}$ & & & 3 & & $\begin{array}{l}\text { *No effect in Wallis and Dollard (2008): } \\
\text { farm-specific resources explained MWB } \\
\text { instead }\end{array}$ \\
\hline $\begin{array}{l}\text { Significance/ } \\
\text { meaningfulness }\end{array}$ & 5 & & & $2^{*}$ & 7 & & $\begin{array}{l}\text { *Two studies report findings suggestive } \\
\text { of 'inverse U' relationship, see } \\
\text { manuscript text }\end{array}$ \\
\hline $\begin{array}{l}\text { Variety/ } \\
\text { interesting work }\end{array}$ & 4 & & & & 4 & & \\
\hline Task identity & & 1 & & & 1 & & \\
\hline Feedback & 2 & & & & 2 & & \\
\hline $\begin{array}{l}\text { Positive work } \\
\text { resources }\end{array}$ & 1 & & & & 1 & & \\
\hline \multicolumn{8}{|l|}{ Stressors } \\
\hline Demands & $1^{*}$ & $2 * *$ & 19 & & 22 & 3 & $\begin{array}{l}\text { *Positive effect for new entrepreneurs: } \\
\text { demands seemed to signal that the } \\
\text { business is going well (Bradley \& } \\
\text { Roberts, 2004), }{ }^{* *} \text { see manuscript text }\end{array}$ \\
\hline Role stressors & & & 6 & & 6 & & \\
\hline $\begin{array}{l}\text { Long/ intense } \\
\text { working hours }\end{array}$ & $2 *$ & 1 & 8 & 2 & 13 & 1 & $\begin{array}{l}\text { *See manuscript text for positive effects } \\
\text { and discussion of recovery effects }\end{array}$ \\
\hline \multicolumn{5}{|c|}{ Personal characteristics ${ }^{2}$} & 53 & 14 & \\
\hline Traits & & & & & 27 & 8 & \\
\hline \multicolumn{8}{|l|}{ Resources } \\
\hline $\begin{array}{l}\text { Psychological } \\
\text { capital }\end{array}$ & 4 & & & & 4 & 1 & $\begin{array}{l}\text { Two studies investigated the } \\
\text { psychological capital construct; one } \\
\text { study each investigated constituent traits } \\
\text { (hope, self-esteem). }\end{array}$ \\
\hline Self-efficacy & 3 & & & $1^{*}$ & 4 & 2 & *See manuscript text \\
\hline Optimism & 1 & & $1^{*}$ & $1^{*}$ & 3 & 2 & *See manuscript text \\
\hline $\begin{array}{l}\text { Emotional } \\
\text { intelligence/ trait } \\
\text { emotion } \\
\text { regulation }\end{array}$ & 3 & & 1 & $2 *$ & 6 & 1 & $\begin{array}{l}\text { *Emotional intelligence mitigates the } \\
\text { negative effects of fear of failure } \\
\text { (Bahmannia et al., 2013); affect spin, as } \\
\text { an emotional experience pattern that } \\
\text { requires emotion-regulation resources is } \\
\text { related to distress (Uy et al., 2017) }\end{array}$ \\
\hline Coping & 4 & & & & 4 & 1 & $\begin{array}{l}\text { See manuscript text for distinct effects } \\
\text { of different copying styles. }\end{array}$ \\
\hline $\begin{array}{l}\text { Internal locus of } \\
\text { control }\end{array}$ & $3 *$ & & & & 3 & 1 & $\begin{array}{l}\text { *Indirect effect of internal locus of } \\
\text { control on distress via role stress in one } \\
\text { study (Wincent \& Örtqvist, 2009). }\end{array}$ \\
\hline Risk tolerance & 2 & & & & 2 & 0 & \\
\hline
\end{tabular}




\begin{tabular}{|c|c|c|c|c|c|c|c|}
\hline \multirow[t]{2}{*}{ Antecedent } & \multicolumn{4}{|c|}{ Effect on MWB } & \multirow{2}{*}{$\begin{array}{l}\text { Total } \\
\text { N of } \\
\text { studies }\end{array}$} & \multirow{2}{*}{$\begin{array}{l}\mathrm{N} \text { stronger } \\
\text { research } \\
\text { designs } \\
\end{array}$} & \multirow{2}{*}{ Notes } \\
\hline & + & 0 & - & Other & & & \\
\hline $\begin{array}{l}\text { Three Big } 5 \\
\text { traits: } \\
\text { agreeableness, } \\
\text { extraversion, } \\
\text { conscientiousness }\end{array}$ & 2 & & & & 2 & 0 & $\begin{array}{l}\text { No relationships for openness to } \\
\text { experience (Berglund, Johansson Sevä, } \\
\& \text { Strandh, 2016; Morrison, 1997). } \\
\text { For emotional stability see findings } \\
\text { below for 'neuroticism'. }\end{array}$ \\
\hline Innovativeness & 2 & & & & 2 & 0 & \\
\hline Positive affect & 1 & & & & 1 & 1 & \\
\hline \multicolumn{8}{|l|}{ Vulnerabilities } \\
\hline $\begin{array}{l}\text { Neuroticism, } \\
\text { negative or } \\
\text { depressed affect }\end{array}$ & & & 5 & $1^{*}$ & 6 & 1 & $\begin{array}{l}\text { *Being emotionally unstable was } \\
\text { recognized by entrepreneurs themselves } \\
\text { as a vulnerability (Ahmad \& Arabia, } \\
2010 \text { ) }\end{array}$ \\
\hline Fear of failure & & & 1 & & 1 & 0 & \\
\hline Human capital & & & & & 13 & 5 & \\
\hline \multicolumn{8}{|l|}{ Resources } \\
\hline $\begin{array}{l}\text { Stress/ self- } \\
\text { management skills }\end{array}$ & 2 & & & & 2 & 2 & \\
\hline $\begin{array}{l}\text { Business \& entre- } \\
\text { preneurial skills }\end{array}$ & 1 & & & $2 *$ & 3 & 1 & $\begin{array}{l}\text { *Lack of business skill recognized by } \\
\text { entrepreneurs as stressor (Ahmad \& } \\
\text { Arabia, 2010; Vaag et al., 2014) }\end{array}$ \\
\hline $\begin{array}{l}\text { Entrepreneurship/ } \\
\text { Leadership } \\
\text { Experience }\end{array}$ & 1 & & 1 & 2 & 4 & 0 & $\begin{array}{l}\text { See manuscript text for explanation of } \\
\text { mixed results }\end{array}$ \\
\hline Education & 1 & & 2 & $2^{*}$ & 5 & 2 & $\begin{array}{l}\text { * Higher education mitigated the } \\
\text { negative effect of financial problems on } \\
\text { well-being (Annink et al., 2016); } \\
\text { perceived mismatch between highest } \\
\text { degree and current work was associated } \\
\text { with lower work satisfaction (Bender \& } \\
\text { Roche, 2013) }\end{array}$ \\
\hline \multicolumn{5}{|l|}{ Values and motivations } & 12 & 0 & \\
\hline \multicolumn{8}{|l|}{\begin{tabular}{l|l} 
Resources & \\
\end{tabular}} \\
\hline $\begin{array}{l}\text { Specific intrinsic } \\
\text { values }\end{array}$ & 5 & & & & 5 & 0 & $\begin{array}{l}\text { Intrinsic values include values of } \\
\text { autonomy, creativity, and well-being }\end{array}$ \\
\hline $\begin{array}{l}\text { General intrinsic } \\
\text { motivation }\end{array}$ & 6 & & & & 6 & 0 & Includes valuing non-financial success \\
\hline $\begin{array}{l}\text { Meeting own expe- } \\
\text { ctations \& goals }\end{array}$ & 3 & & & & 3 & 0 & \\
\hline $\begin{array}{l}\text { Valuing } \\
\text { achievement }\end{array}$ & 1 & & & & 1 & 0 & \\
\hline \multicolumn{8}{|l|}{ Vulnerability } \\
\hline $\begin{array}{l}\text { Valuing financial } \\
\text { success, money \& } \\
\text { extrinsic motives }\end{array}$ & & & 3 & & 3 & 0 & \\
\hline \multicolumn{5}{|c|}{ Other personal characteristics } & 8 & 2 & \\
\hline $\begin{array}{l}\text { Physical health \& } \\
\text { health behaviors }\end{array}$ & 5 & $1 *$ & & & 6 & 1 & $\begin{array}{l}\text { * One longitudinal study found no } \\
\text { relationship between height as a proxy } \\
\text { for good physical health and } \\
\text { entrepreneurs' MWB (Rietveld, Hessels, } \\
\text { \& Van der Zwan, 2015) }\end{array}$ \\
\hline $\begin{array}{l}\text { Immigrant } \\
\text { entrepreneur }\end{array}$ & 2 & & & & 2 & 1 & \\
\hline \multicolumn{5}{|c|}{ Firm and financial characteristics ${ }^{2}$} & 37 & 15 & \\
\hline
\end{tabular}




\begin{tabular}{|c|c|c|c|c|c|c|c|}
\hline \multirow[t]{2}{*}{ Antecedent } & \multicolumn{4}{|c|}{ Effect on MWB } & \multirow{2}{*}{$\begin{array}{l}\text { Total } \\
\text { N of } \\
\text { studies }\end{array}$} & \multirow{2}{*}{$\begin{array}{l}\mathrm{N} \text { stronger } \\
\text { research } \\
\text { designs } \\
\end{array}$} & \multirow{2}{*}{ Notes } \\
\hline & + & 0 & - & Other & & & \\
\hline \multicolumn{8}{|l|}{ Resources } \\
\hline $\begin{array}{l}\text { Financial rewards/ } \\
\text { income }\end{array}$ & 6 & & & & 6 & 2 & \\
\hline $\begin{array}{l}\text { Perceived firm } \\
\text { success }\end{array}$ & $5^{*}$ & & & $1 * *$ & 6 & 1 & $\begin{array}{l}* \text { Measured in one study as entrepreneur } \\
\text { reports of firm productivity (Sherman, } \\
\text { Randall, \& Kauanui, 2016) ** qualitative } \\
\text { research, see manuscript text }\end{array}$ \\
\hline $\begin{array}{l}\text { Objective firm } \\
\text { performance }\end{array}$ & & $1 *$ & $1^{*}$ & & 2 & 1 & *See manuscript text for explanation \\
\hline $\begin{array}{l}\text { Number of } \\
\text { employees }\end{array}$ & 3 & & $1^{*}$ & & 4 & 3 & *See manuscript text for explanation \\
\hline $\begin{array}{l}\text { Financial resources } \\
\text { (loan) }\end{array}$ & & & $1^{*}$ & 1 & 2 & 2 & *See manuscript text for explanation \\
\hline \multicolumn{8}{|l|}{ Stressors } \\
\hline Financial problems & & 1 & 7 & 1 & 8 & 4 & See manuscript text for detailed findings \\
\hline Low pay/income & & & 3 & & 3 & 0 & \\
\hline Job loss & & & 5 & & 5 & 4 & $\begin{array}{l}\text { Includes studies on unemployment and } \\
\text { retirement }\end{array}$ \\
\hline $\begin{array}{l}\text { Job insecurity/ } \\
\text { uncertainty }\end{array}$ & & & 5 & & 5 & 1 & \\
\hline Other & & & $2 *$ & & 2 & 0 & $\begin{array}{l}\text { *Income uncertainty and perceived } \\
\text { financial responsibility (for self and } \\
\text { family) identified as stressors in } \\
\text { qualitative studies (Sörensson \& } \\
\text { Dalborg, 2017; Schonfeld \& Mazzola, } \\
\text { 2015). }\end{array}$ \\
\hline \multicolumn{5}{|c|}{ Social resources and stressors ${ }^{2}$} & 25 & 6 & \\
\hline \multicolumn{8}{|c|}{\begin{tabular}{|l|l|l} 
Resources & \\
\end{tabular}} \\
\hline $\begin{array}{l}\text { Social support/ low } \\
\text { loneliness }\end{array}$ & 11 & & & $2 *$ & 13 & 3 & $\begin{array}{l}\text { *Moderating effect of social capital: } \\
\text { social capital mitigates the negative } \\
\text { effect of fear of failure on work stress } \\
\text { in non-family owned businesses } \\
\text { (Bahmannia et al., 2013). Work- } \\
\text { related social support buffered the } \\
\text { effect of exhaustion on job satisfaction } \\
\text { (no effect of exhaustion when work- } \\
\text { related support was available, Tetrick } \\
\text { et al., 2000). }\end{array}$ \\
\hline $\begin{array}{l}\text { Work Family } \\
\text { Enrichment (WFE) }\end{array}$ & 3 & & & & 3 & 1 & \\
\hline $\begin{array}{l}\text { Positive feedback } \\
\text { from customers }\end{array}$ & & & & $2 *$ & 2 & 1 & $\begin{array}{l}\text { *Feedback from clients emerged as } \\
\text { source of MWB in qualitative studies } \\
\text { (Anderson \& Hughes, 2010; Lechat \& } \\
\text { Torrès, 2017). }\end{array}$ \\
\hline \multicolumn{8}{|l|}{ Stressors } \\
\hline $\begin{array}{l}\text { Work Family } \\
\text { Conflict (WFC) }\end{array}$ & & & 8 & $1 *$ & 9 & 2 & $\begin{array}{l}\text { *Negative effect of WFC on MWB for } \\
\text { women entrepreneurs only. }\end{array}$ \\
\hline Family conflicts & & & 1 & & 1 & 0 & \\
\hline $\begin{array}{l}\text { Customer \& } \\
\text { employee conflicts }\end{array}$ & & & & 2 & 2 & 1 & \\
\hline Partner control & & & 1 & & 1 & 0 & \\
\hline $\begin{array}{l}\text { Responsibility for } \\
\text { people at work }\end{array}$ & & & 1 & & 1 & 0 & \\
\hline
\end{tabular}




\begin{tabular}{|c|c|c|c|c|c|c|c|}
\hline \multirow[t]{2}{*}{ Antecedent } & \multicolumn{4}{|c|}{ Effect on MWB } & \multirow{2}{*}{$\begin{array}{c}\text { Total } \\
\text { N of } \\
\text { studies }\end{array}$} & \multirow{2}{*}{$\begin{array}{l}\text { N stronger } \\
\text { research } \\
\text { designs }{ }^{1} \\
\end{array}$} & \multirow{2}{*}{ Notes } \\
\hline & + & 0 & - & Other & & & \\
\hline \multicolumn{5}{|c|}{ Context characteristics $^{2}$} & 25 & 6 & \\
\hline $\begin{array}{l}\text { Business climate/ } \\
\text { market demand }\end{array}$ & 2 & & & 3 & 5 & 2 & \\
\hline $\begin{array}{l}\text { Economic } \\
\text { recession }\end{array}$ & & 1 & 3 & & 4 & 0 & \\
\hline $\begin{array}{l}\text { High levels of } \\
\text { market competition }\end{array}$ & & & 2 & & 2 & 2 & \\
\hline $\begin{array}{l}\text { Societal esteem of } \\
\text { entrepreneurs }\end{array}$ & 2 & & & $1^{*}$ & 3 & 0 & $\begin{array}{l}\text { *Moderating effect, see manuscript } \\
\text { text }\end{array}$ \\
\hline Regulation & 1 & & 1 & & 2 & 0 & $\begin{array}{l}\text { Regulation to enhance } \\
\text { competitiveness was positively related } \\
\text { to entrepreneurs' MWB across } \\
\text { countries (Cuellar-Molina, Lucia- } \\
\text { Casademunt, \& Garcia-Cabrera, } \\
\text { 2015), but individual entrepreneurs } \\
\text { experienced regulation as strain on } \\
\text { MWB (Kalliomeni et al., 2016) }\end{array}$ \\
\hline Shock & 1 & & 4 & & 5 & 2 & see manuscript text \\
\hline Other & & & & 6 & 6 & 0 & $\begin{array}{l}\text { Entrepreneurs' MWB varies across } \\
\text { countries (Benz \& Frey, 2008; } \\
\text { Schneck, 2014) and industries (Rau et } \\
\text { al., 2008). Labour market } \\
\text { flexibilization affects entrepreneurs' } \\
\text { MWB less than employees MWB } \\
\text { (Obschonka \& Silbereisen, 2015). } \\
\text { Social and religious obligations in the } \\
\text { community were stressors for female } \\
\text { entrepreneurs (Ugwu et al., 2016). } \\
\text { Country differences in unemployment } \\
\text { insurance and social trust moderated } \\
\text { the effects of financial hardships on } \\
\text { MWB (Annink et al., 2016). }\end{array}$ \\
\hline \multicolumn{5}{|c|}{ Physical environment $^{2}$} & 4 & $\mathbf{0}$ & \\
\hline \multicolumn{8}{|l|}{ Resource } \\
\hline Being in nature & 1 & & & & 1 & 0 & \\
\hline \multicolumn{8}{|l|}{ Stressor } \\
\hline $\begin{array}{l}\text { Physical demands, } \\
\text { workload \& danger }\end{array}$ & & & 4 & & 4 & 0 & \\
\hline
\end{tabular}

Notes.

${ }^{1}$ longitudinal, lagged, experimental, experience sampling studies

${ }^{2}$ Individual studies may contain information on more than one characteristic. Hence, the total number of studies for a cluster of characteristics may be smaller than the sum of studies across each of the individual characteristics. 
Table 2. Overview of Review Findings on the Consequences of Entrepreneurs' MWB

\begin{tabular}{|c|c|c|c|c|c|c|c|}
\hline \multirow[t]{2}{*}{ Outcome } & \multicolumn{4}{|c|}{ Consequence of MWB } & \multirow{2}{*}{$\begin{array}{l}\text { Total } \\
\mathbf{N} \text { of } \\
\text { studies }\end{array}$} & \multirow{2}{*}{$\begin{array}{l}\mathrm{N} \text { with } \\
\text { stronger } \\
\text { research } \\
\text { designs }^{1} \\
\end{array}$} & \multirow{2}{*}{ Notes } \\
\hline & + & 0 & - & Other & & & \\
\hline \multicolumn{4}{|c|}{ Performance-related outcomes ${ }^{2}$} & & 28 & 10 & \\
\hline Persistence & $6^{*}$ & & $1 * *$ & & 7 & 3 & $\begin{array}{l}\text { *In one study this effect } \\
\text { was contingent on social } \\
\text { capital. }{ }^{*} \text { One descriptive } \\
\text { study without controls. }\end{array}$ \\
\hline Firm performance & 7 & & 1 & & 8 & 3 & \\
\hline $\begin{array}{l}\text { Opportunity } \\
\text { recognition }\end{array}$ & 5 & & $1^{*}$ & & 5 & 0 & $\begin{array}{l}\text { *In Foo (2011) happiness } \\
\text { and anger had the same } \\
\text { effects on opportunity } \\
\text { recognition. }\end{array}$ \\
\hline $\begin{array}{l}\text { Effort towards } \\
\text { goals }\end{array}$ & 2 & & $1^{*}$ & & 2 & 1 & $\begin{array}{l}\text { *In Foo et al (2009) both } \\
\text { positive and negative } \\
\text { affect facilitated effort but } \\
\text { towards different goals. }\end{array}$ \\
\hline Absenteeism & 2 & & & & 2 & 0 & \\
\hline Proactive behaviors & 1 & & & & 1 & 1 & \\
\hline $\begin{array}{l}\text { Outcomes for the } \\
\text { entrepreneur (ill } \\
\text { health, stress) }\end{array}$ & & & 2 & & 2 & 2 & \\
\hline $\begin{array}{l}\text { Outcomes for others } \\
\text { (partners, children, } \\
\text { tolerance towards } \\
\text { others) }\end{array}$ & 3 & & 1 & & 4 & 2 & \\
\hline
\end{tabular}

Notes.

${ }^{1}$ longitudinal, lagged, experimental, experience sampling studies

${ }^{2}$ Individual studies may contain information on more than one outcome. Hence, the sum of studies across the individual outcomes appears greater than 28 . 
Table 3. Entrepreneurs' MWB: Summary of Opportunities for Future Contributions (elaborations in manuscript text)

The nature of entrepreneurs' MWB

- What are possible 'functionalities' of low MWB? In what way are feelings of distress, discontentment, and symptoms of mental disorders (beyond ADHD) 'functional' to motivate entrepreneurial actions and for positive outcomes?

- What are the consequences of the variability and balance between well-being and distress? Are they related to entrepreneurs' performance and resilience, and if so, how?

- Greater attention to entrepreneurs' eudaimonic well-being (e.g., thriving, meaning, selfrealization): What are the specific antecedents of entrepreneurs' eudaimonic well-being?

- To what extent is the high hedonic well-being of entrepreneurs driven by self-justification processes to reduce cognitive dissonance?

The nature of entrepreneurs' work (stressors and resources relevant for MWB)

- What role do volatility and fluctuations in stressors and resources play for entrepreneurs' MWB - beyond considering their mean levels?

- Are we investigating the 'right kind' of stressors? What stressors might act as challenge or hindrance stressors, and when and how?

- How should we conceptualize the enmeshment of entrepreneurs' work with their private and social life? Can this help to explain MWB differences between the genders?

- How can we incorporate firm and market context into theories of entrepreneurs' work?

- How do entrepreneurs' craft their own work, social, financial demands, and resources?

- When and how might entrepreneurs' work change their personality?

Unpacking the trade-offs inherent in entrepreneurs' work

- When and how might autonomy have potential detrimental effects? Are there curvilinear effects? When and how might autonomy lead entrepreneurs to overexert themselves?

- How can the centrality of entrepreneurs' work for their identity be better recognized? How might entrepreneurs' passion and thriving develop into obsession and addiction?

- What short- and long-term productivity and health trade-offs are there? What is the role of recovery? What recovery processes and activities do entrepreneurs engage in?

- Are there trade-offs between entrepreneurs' MWB and the MWB of their employees?

Contextualizing research on entrepreneurs' MWB

- What are the MWB resources and stressors associated with different types/ forms of entrepreneurship (e.g., growth-oriented, necessity, social, informal, family business)?

- How can the documented MWB differences across countries be explained? What role do formal institutions and culture play? Through which processes do they affect MWB?

Expanding our understanding of the consequences of entrepreneurs' MWB

- Beyond opportunity recognition, effort, and performance, what other outcomes does entrepreneurs' MWB affect?

- (How) Does entrepreneurs' MWB create crossover effects, influencing the MWB of their stakeholders? (How) Does entrepreneurs' MWB relate to collective outcomes? How does MWB relate to prosocial behavior, ethical decisions, and transgressions?

Towards greater plurality of research designs and methods

- What methods can complement the current dominance of theory-testing and crosssectional research? Experiment with longitudinal qualitative research, ethnography, work-shadowing, physiological and other-ratings of entrepreneurs' MWB.

- Over what time-frame should longitudinal, process, and diary-studies be conducted to capture micro processes, changes in MWB, its antecedents and consequences?

- Use multi-level studies to unpack influences of national or community contexts on entrepreneurs' MWB, and to discern how entrepreneurs' MWB affects their employees. 
Figure 1. Overview of Research on Entrepreneurs' MWB: Research Streams and Examples of Concepts Studied (Number of studies in brackets)

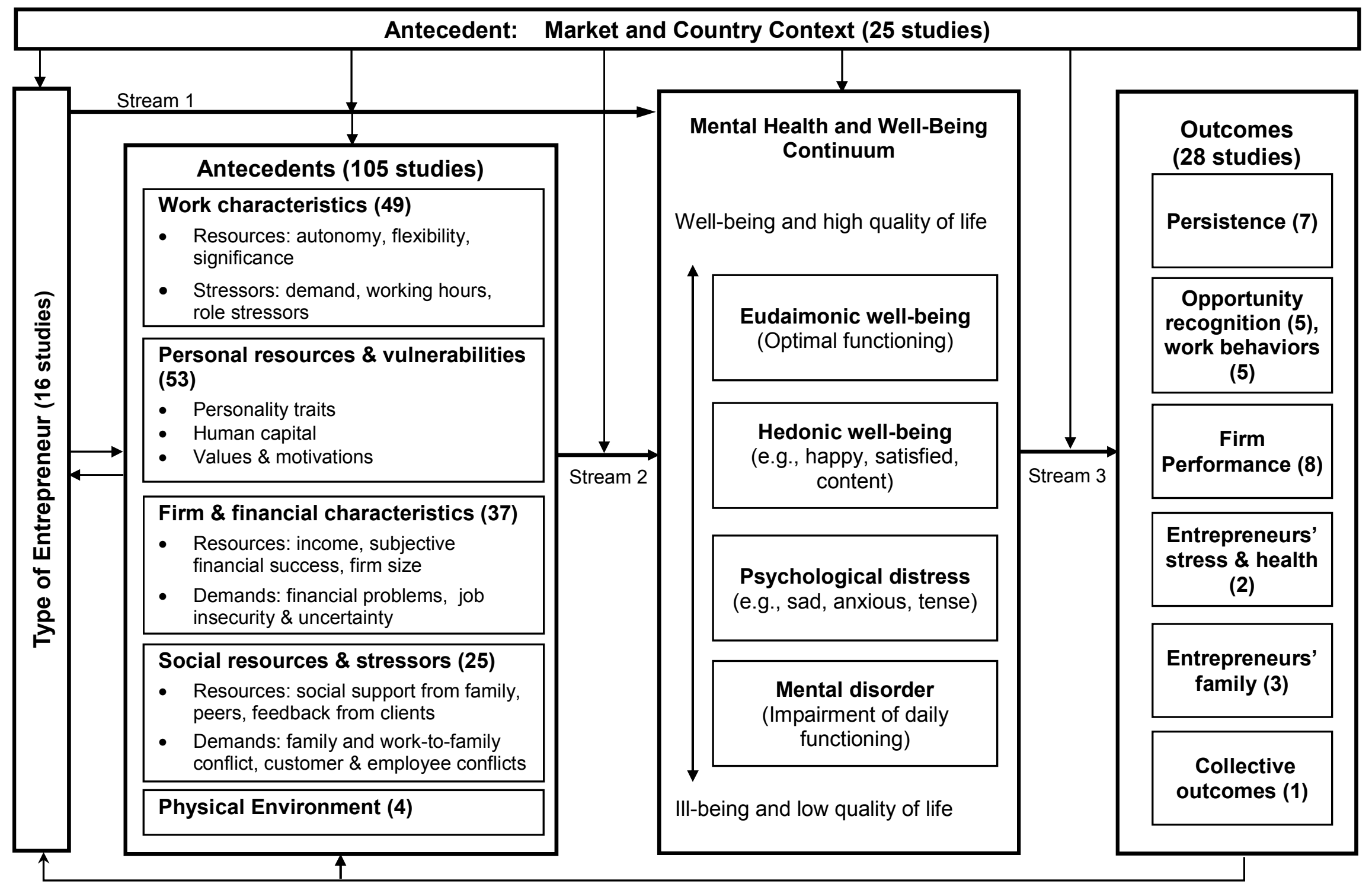


Figure 2. Consequences of Entrepreneurs' MWB: Summary of Review Findings, Gaps and Possible Dynamic Relationships

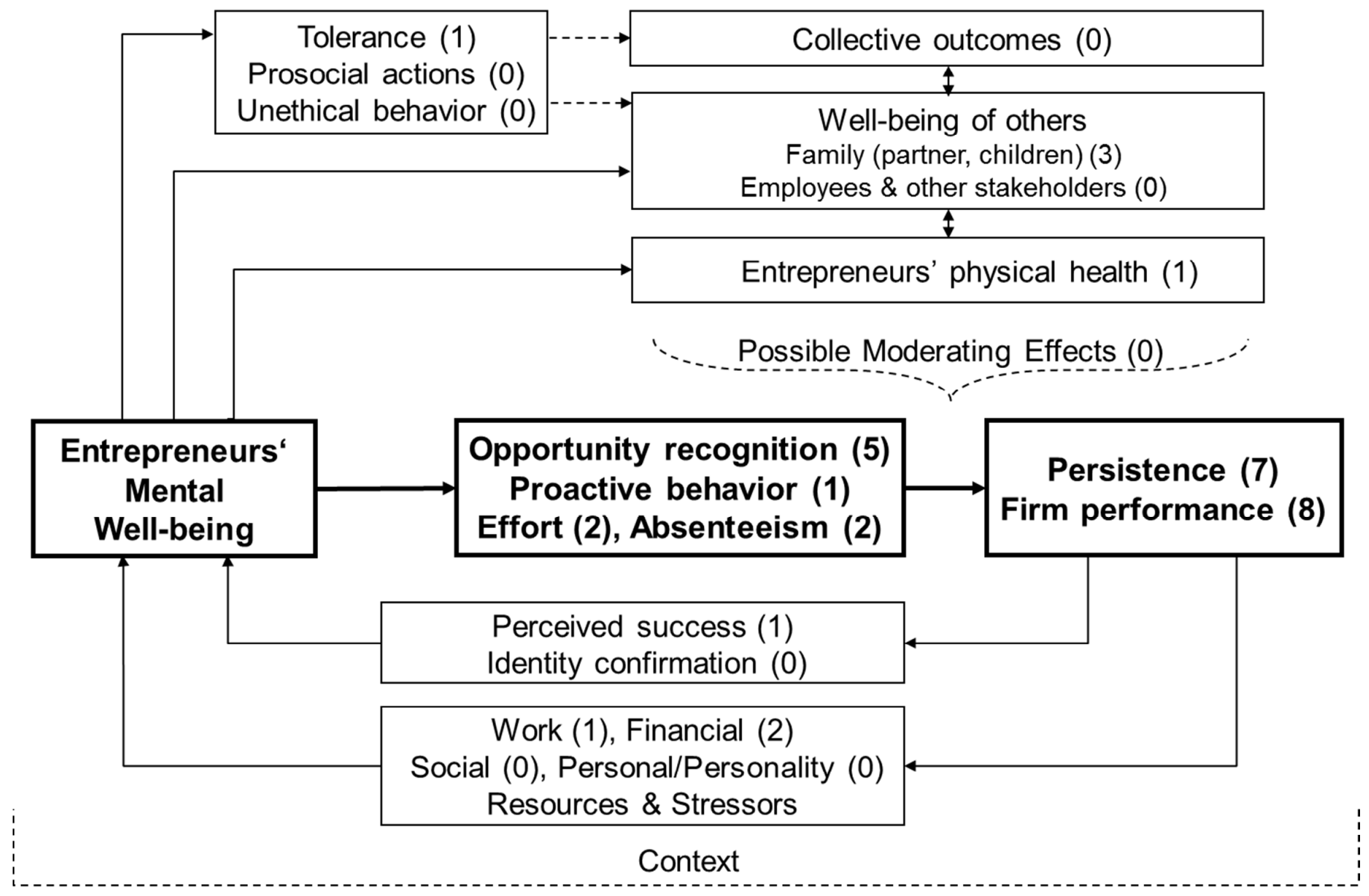

Note. Bold font highlights the most frequently researched concepts and relationships. Numbers in brackets indicate the number of studies in the review reporting relevant evidence. Dashed lines indicate newly proposed relationships. All relationships refer to the individual-level, except relationships with firm-performance (individual to firm level), relationships with the well-being of others (which imply crossover effects from the individual entrepreneur to others), and relationships with collective outcomes (which imply individual to collective-level relationships). See manuscript text for details. 
Ute Stephan (u.stephan@aston.ac.uk) is Professor of Entrepreneurship at Aston Business School, Aston University and Editor-in-Chief of Applied Psychology: An International Review. Her research examines the interplay of culture, institutions and entrepreneurship; investigates social entrepreneurship and inclusive business; and explores entrepreneurial motivation and well-being. 